\title{
Inflammatory bowel disease (IBD) position statement of the Italian Society of Colorectal Surgery (SICCR): general principles of IBD management
}

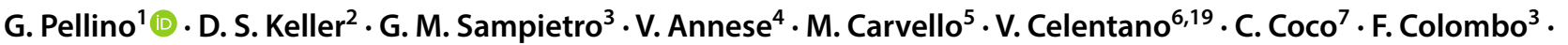

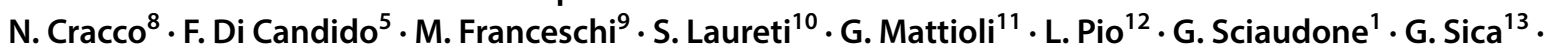 \\ V. Villanacci ${ }^{14} \cdot$ R. Zinicola $^{15} \cdot$ S. Leone ${ }^{16} \cdot$ S. Danese ${ }^{17} \cdot$ A. Spinelli ${ }^{5} \cdot$ G. Delaini ${ }^{18} \cdot$ F. Selvaggi $^{1}$ on behalf of the Italian \\ Society of Colorectal Surgery (SICCR)
}

Received: 18 November 2019 / Accepted: 23 December 2019 / Published online: 25 January 2020

(c) Springer Nature Switzerland AG 2020

\begin{abstract}
The Italian Society of Colorectal Surgery (SICCR) promoted the project reported here, which consists of a Position Statement of Italian colorectal surgeons to address the surgical aspects of inflammatory bowel disease management. Members of the society were invited to express their opinions on several items proposed by the writing committee, based on evidence available in the literature. The results are presented, focusing on relevant points. The present paper is not an alternative to available guidelines; rather, it offers a snapshot of the attitudes of SICCR surgeons about the general principles of surgical treatment of inflammatory bowel disease. The committee was able to identify some points of major disagreement and suggested strategies to improve quality of available data and acceptance of guidelines.
\end{abstract}

Keywords Inflammatory bowel disease · Crohn's disease · Ulcerative colitis · Inflammatory bowel diseases · Surgery · Pouch

\section{Introduction}

Patients with inflammatory bowel diseases (IBD) need to be treated in specialized centers under the care of multidisciplinary teams. Both Crohn's disease (CD) and ulcerative colitis (UC) require expertise and dedicated facilities. Several international societies have been developing authoritative guidelines to aid the management of IBD [1-12]. In 2015, the Italian Society of Colorectal Surgery (SICCR) conducted a Delphi exercise involving Italian experts, members of the society, concerning the surgical management of IBD [13, 14] and several areas of moderate agreement were identified. This is the third manuscript resulting from the SICCR project repeated in 2019, dealing with the general principles of IBD management. As reported in the first manuscript

List of members for The Italian Society of Colorectal Surgery SICCR are given in acknowledgement section.

G. Pellino

gipe1984@gmail.com

Extended author information available on the last page of the article from the 2019 SICCR project [13], the current manuscript is not intended to replace the available guidelines; rather, it should stimulate discussion about the surgical issues of IBD among experts at a national level and draw attention to the importance of applying pathways of management in everyday practice nationally. A patient representative was involved in the entire process.

This position statement does not set forth strict rules of conduct, rather it should be interpreted as a decisional aid to be adapted to each individual patient.

\section{Methods}

The methods have been thoroughly described in the manuscript in the Position Statement for the surgical treatment of CD [13].

Briefly, a steering committee of experts, including a patient representative (SL), an external advisor (DSK), and an external expert supervisor (SD), identified experts who were invited to participate in the project. Each collaborator contributed with a specific section and drafted the 
statements with evidence levels (EL) graded according to "The Oxford Levels of Evidence 2" of Oxford Centre for Evidence-Based Medicine OCEBM (https://www.cebm. net/index.aspx?o=5653), along with a brief supporting text. Contributions were circulated via SurveyMonkey (SurveyMonkey Inc., San Mateo, CA, USA, www.surveymonk ey.com). Answers were reviewed by the steering committee, and statements and supporting text that achieved less than $80 \%$ of agreement reviewed and submitted for a second round of voting.

Statements that did not achieve $80 \%$ were either deleted or moved to the supporting text. Some statements with " $>80 \%$ agreement" were revised to include the comments received.

\section{Perioperative phase}

\section{Disease assessment}

\section{Item 1}

Diagnosis of IBD requires a combination of clinical, endoscopic, radiological, and histological investigations (EL 3). None of these, alone, is specific for Crohn's disease (CD) or ulcerative colitis (UC) (EL3). [Agreement: "Agree" 94.1\%, "Partially agree" 5.9\%, round II]

Diarrhea for 6 weeks, rectal bleeding, abdominal pain, weight loss and low energy level are the main clinical features common to both the diseases [14]. The most invalidating symptom in UC is urgency in up to $73 \%$ of patients [15]. It is important to assess urgency [16]. Colonoscopy with intubation of the terminal ileum is the preferred investigation to study the mucosa, but there is no single specific endoscopic feature for UC and CD. Endoscopic biopsies have less diagnostic accuracy than surgical specimen examination. In fact, even in referral IBD centers, following ileo-anal pouch construction the reclassification of UC into CD occurs in up to $10 \%$ of cases [17]. There is not a single histological lesion in UC that is not present in $\mathrm{CD}$, nevertheless the differential diagnosis is the type of infiltration: in UC dense and diffuse, whereas in $\mathrm{CD}$ focal and discontinuous inflammation.

Item 2

The clinical assessment of oral, small bowel and anal canal involvement may help to guide the differential diagnosis between CD and UC (EL4). Extraintestinal manifestations and family history should be investigated (EL5).

[Agreement: "Agree" 100\%, II round]

The mainstay of differential diagnosis (UC vs CD) is still the holistic and global assessment by the clinician.
The simultaneous presence of different clinical features (severe anal disease with small bowel involvement in CD, severe rectal inflammation with oral pyostomatitis vegetans in UC) may be more reliable than any single histological feature. A positive family history of IBD has been reported in $1.5-28 \%$ and $1.5-24 \%$ of $C D$ and UC probands, respectively. Several studies have reported high concordance rates for the type of IBD: for CD and UC familial studies have shown concordance rates of $67-89 \%$ [18].

Item 3

Oral lesions are more common in CD (EL3). Small bowel involvement is specific to $\mathrm{CD}$; a limited involvement of the terminal ileum only does not exclude the diagnosis of UC (EL3).

The incidence of oral lesions in $\mathrm{CD}$ ranges between 20 and $50 \%$. Oral manifestations may occur in $4-10 \%$ of patients with UC. Aphthous ulcers are the most common type in IBD patients [19]. Pyostomatitis vegetans is more frequent in UC than in CD [20]. Backwash ileitis is a condition seen in 10-20\% of total colectomy specimens of patients with ulcerative colitis. Historically, the involvement of the ileocecal valve has been reported as the cause of backwash ileitis [21]. Recently, a prospective case-control study reported terminal ileitis without involvement of the right colon and cecum in $22 \%$ of UC patients. The inflammation was characterized as mild in $94 \%$ of the cases and chronic inactive in $6 \%$. It has been suggested that terminal ileitis is a primary extracolonic manifestation not due to backwash [22].It has been reported that pre-ileal pouch ileitis and prestomal ileitis could be an expression of UC rather than CD [23]. In pre-pouch ileitis, the histology shows a continuous infiltrate similar to UC.

Item 4

Perianal disease is more frequent and aggressive in $\mathrm{CD}$, but may be present in up to $10 \%$ of UC patients (EL3). Gastroenterologists should be familiar with basic assessment of perianal disease to optimize interdisciplinary approach (EL4).

[Agreement: "Agree" 94.1\%, "Disagree" 5.9\%, round II]

Perianal disease is common in CD occurring in $30-70 \%$ of the patients. Perianal manifestations may occur in up to $10 \%$ of the patients with UC. Rectovaginal fistula has been usually considered specific for CD occurring in $10 \%$ of women. Rectovaginal fistula has been reported in 2-3\% of UC patients. The largest series of rectovaginal fistula in UC suggested a correlation with severity of rectal disease (rectal strictures, deep ulceration, widened presacral space), whereas in patients with $\mathrm{CD}$ and recto-vaginal fistula the inflammation may be minimal or mild [24]. 
Item 5

MR enterography should be used in patients with the suspicion of CD and newly diagnosed CD (EL2).

[Agreement: "Agree" 94.1\%, "Disagree" 5.9\%, round II]

Magnetic resonance (MR) enterography is the ideal tool to detect the extent of the disease, active small bowel disease, strictures, abscesses and entero-enteric fistulas [25, 26]. Intestinal ultrasound (US) is cost-effective, simple and does not require sedation and exposure to ionizing radition, but dedicated expertise is required as it is operator dependent [27]. Computed tomography (CT) enterography should be used if MR enterography is not feasible or not tolerated. Small bowel capsule endoscopy can reliably assess mucosal disease, but should be used cautiously if symptoms suggest obstruction or stricturing small bowel CD [28]. The possibility of capsule impaction should be considered, especially in patients with known CD [10, 29]. Small bowel imaging with fluoroscopic barium small bowel follow-through could be used for the initial diagnosis of IBD, as it is a dynamic examination providing information on the distensibility of the small bowel [27]. This may help to differentiate functional from organic stenosis. A prospective study of small bowel follow-through for newly diagnosed IBD reported a sensitivity and specificity of $72 \%$ and $100 \%$ [30]. Nevertheless, for the initial assessment and exclusion of $\mathrm{CD}$, small bowel capsule endoscopy, intestinal US, MR enterography and CT enterography are superior to small bowel followthrough [31]. Recently, the utility of hybrid positron emission tomography (PET)/MR enterography in assessing the degree of inflammation in CD strictures has been reported, with good pathology correlation [32, 33]; however, the examination is not easily available and is expensive.

Item 6

Social life (work, family, sexual activity, leisure time) should be investigated to assess the actual burden of disease (EL4). Specific quality of life scores should be used.

[Agreement: "Agree" 88.2\%, "Partially agree" 5.9\%, "Disagree" $5.9 \%$, round II]

IBD significantly affects patients in their daily life and social functioning (work, education and social life) and treatment must be directed towards improvement of patients' quality of life [34]. Often, the choice to promptly switch toward more aggressive therapy can be made according to worsening of social life functioning rather than of biochemical tests. For example, a patient with normal laboratory tests, but with urgency severely limiting the ability to leave home requires a new therapeutic strategy more than a patient with compromised laboratory results but without any limitations in social life [35]. Several validated disease severity indexes are available, which provide a useful tool for consistent assessment of overall disease severity in patients with IBD [36]. The Inflammatory Bowel Diseases Questionnaire (IBDQ) is considered the gold standard for use in clinical trials, but it might be impractical in clinical practice [37].

Item 7

Several clinical, endoscopic and histological scores have been proposed for IBD assessment, and should be used to monitor disease evolution (EL3).

[Agreement: "Agree" 94.1\%, "Disagree" 5.9\%, round II]

Firstly, a score should assess the type and the anatomical extension of the disease. The UC Montreal classification defines macroscopic anatomical extension into three subgroups: E1: rectum; E2: left side; E3: proximal to splenic flexure. The CD Montreal classification addresses the location (ileum, colon, ileocolon, upper gastrointestinal tract) and behavior (neither, stricturing, penetrating) [38]. Small bowel involvement could be "localized" $(<30 \mathrm{~cm}$ small bowel-ileocecum) or "extensive" ( $>1 \mathrm{~m}$ ileum) [38]. The most common endoscopic severity scores in CD are CDEIS, SES-CD and Rutgeerts Score. CDEIS and SES-CD are incompletely validated, but extensively applied in clinical trials. Rutgeerts score is used to assess postoperative recurrence in the neoterminal ileum. It has not undergone formal validation, but is applied in clinical trials $[39,40]$. UC endoscopic severity scores are CEIS, UCCIS, Baron Score, Mayo Endoscopic Subscore, Powell-Tuck Index, Sutherland Index and PICASSO Score [41]. A recent Cochrane review reported that while the UCEIS, UCCIS and Mayo Clinic Endoscopic Subscore have undergone extensive validation, none of these instruments have been fully validated [42]. Clinical severity indexes are useful for standardizing disease activity and therapy effectiveness. Every clinical score should be easy and quick to use to be suitable for practical use, especially for diseases involving bowel habitus. Most of the clinical scores (CDAI, Mayo clinic score, Truelove-Witts Severity Index, SCCAI, UCDAI), are complex and time consuming.

\section{Multidisciplinary team (MDT) management}

Item 8

Patients with IBD should be managed by an MDT, including at least the following expertise: gastroenterologists, colorectal surgeons, nurses, stoma therapists, gastrointestinal and interventional radiologists, pathologists, nutritionists, specializing in IBD; and other specialists-according to their individual needs (EL 4).

[Agreement: "Agree" 100\%, round II] 
Adapted from Brown et al. [8], the aims of an MDT are to advance patient care, provide multidisciplinary input for the patient's care plan, provide shared experience and expertise, improve patient outcome, deliver the best possible care for the patient and obtain consensus on management for a patient with IBD [43]. The introduction of an IBD nurse led to better quality of care and potentially significant cost savings by reducing hospitalization rates and reallocating physician's time resources [44]. Psychological support should also be made available for IBD patients as part of the MDT [8].

Item 9

Options of IBD treatment should be clearly discussed with patients, who should be actively involved in the treatment decision making (EL4).

[Agreement: "Agree" 94.1\%, "Partially agree" 5.9\%, round II]

$\mathrm{UC}$ and $\mathrm{CD}$ both have repeated relapses and recurrences with symptoms affecting patients in different ways. Therefore, it is imperative that the patients are involved in treatment decisions [45]. The different specialists of the MDT must communicate as much as possible to ensure the best management of the different phases of the disease [46].

\section{Perioperative optimization}

\section{Item 10}

Prednisolone $\geq 20 \mathrm{mg}$ daily for $>6$ weeks could be a risk factor for postoperative complications (EL4). Preoperative azathioprine/mercaptopurine does not seem to increase the risk (EL3).

[Agreement: "Agree" 88.2\%, "Disagree" 11.8\%, round II]

Many retrospective studies indicate that a preoperative dose of $>20 \mathrm{mg}$ of prednisolone for $>6$ weeks increases the risk of surgical complications [47, 48]. An increase in infective complications and in short-term postoperative pouchspecific complications has been demonstrated. Therefore, patients should be weaned from steroids before surgery whenever possible, otherwise pouch construction should be delayed. It is important to reduce steroid dosage after surgery taking care to avoid the risk of an Addisonian crisis. Mahadevan and colleagues have shown that preoperative treatment with azathioprine/mercaptopurine, even if very close to surgery, does not increase the risk of postoperative complication [49].

Several studies have tried to define the risk of postoperative complications associated with the use of preoperative infliximab, but the results are quite conflicting [50]. There are no randomized studies, but only observational and retrospective series. A meta-analysis [51] published in 2010 showed an increase in short-term postoperative septic complications, but subsequent studies $[52,53]$ failed to demonstrate this correlation. Generally, an interval before surgery of 4-6 weeks from the last dose of infliximab is advised [54] and the standard recommendation is to not perform a single stage restorative proctocolectomy in patients currently on anti-tumor necrosis factor (TNF) treatment $[55,56]$.

More detailed information in CD and UC specifically is reported in the dedicated manuscripts [13].

Item 11

Enteral nutrition or exclusive enteral nutrition may reduce the risk of septic complications in malnourished and fistulizing CD patients (EL3). There are no sufficient data to define the role of parenteral nutrition in the perioperative phase and it should be used only if enteral nutrition is contraindicated (EL3).

[Agreement: "Agree" 72.2\%, "Partially agree 16.7\%, "Neutral" 5.6\%, "Disagree" 5.6\%, round I]

An extensive review on nutritional support in IBD patients has been recently published [57]. It has been demonstrated that preoperative exclusive enteral nutrition in patients with fistulizing $\mathrm{CD}$ is associated with a significantly decreased risk of intra-abdominal septic complications and may result in an accelerated recovery and ability to return to work sooner [58]. Enteral nutrition has not been adequately evaluated in active UC and its efficacy needs to be tested in larger cohorts of patients [59]. Surgical intervention in IBD patients should ideally be delayed for 7-14 days whenever possible if malnutrition is identified. In this time, intensive artificial feeding with enteral nutrition should be initiated [59]. Parenteral nutrition should be considered preoperatively only if metabolic needs are not met by enteral nutrition alone or if disease presentation at the time of surgery impedes the use of enteral nutrition [60].

Item 12

Surgery for IBD has an increased risk of thromboembolic complications. Postoperative venous thromboembolism prophylaxis is advised (EL3)

[Agreement: "Agree" $72.2 \%$, "Partially agree $22.2 \%$,

"Neutral" 5.6\%, round I]

Compared with the general population, patients with IBD have been shown to have a two- to threefold increased risk of venous thromboembolism [61, 62]. The risk of venous thromboembolism in IBD patients is further increased twofold following surgery or admission to the hospital with a $\mathrm{CD}$ or UC flare; the latter accounts for over $30 \%$ of venous thromboembolism in all IBD patients $[63,64]$. Patients hospitalized with active IBD should receive thromboprophylaxis at admission $[1,65]$. In a recent study by Brady et al. [66], 7078 patients undergoing surgery for $\mathrm{CD}$ or $\mathrm{UC}$ were evaluated. Postdischarge thromboembolism was more common in patients with UC than with CD (5.8\% vs $2.3 \%$; 
$p<0.001)$. There are sufficient data indicating that continuing postoperative venous thromboembolism prophylaxis for 4 weeks reduces occurrence of venous thromboembolism complications in patients undergoing laparoscopic colectomy for colon and rectal cancer [67]. Similar recommendations should be applied to patients with IBD to reduce postoperative venous thromboembolism.

\section{Assessment of outcome}

\section{Item 13}

Assessment of outcome of therapeutic interventions for IBD patients is necessary and strongly recommended (EL4), but the ideal outcome measures have not yet been established univocally.

[Agreement: "Agree" 88.2\%, "Partially agree 5.9\%, "Disagree" $5.9 \%$, round II]

In recent years, the importance of patient-reported outcome measures has been increasingly recognized [68, 69]. There is large consensus that IBD patients should be assessed on a regular basis $[11,70]$, but there is little agreement as to which measures in particular should be used. In neoplastic disease, a natural outcome to assess would be survival and disease-free survival, given the major impact on these parameters. In IBD on the other hand, where there is a smaller impact on survival [71], a more tailored outcome measurement must take into account symptoms, function and quality of life. It has been demonstrated that when physicians are compelled to report on patient outcomes, there is a marked improvement in the results of their care [72, 73].

One expert consensus (STRIDE) has tried to define not only which outcomes to monitor, but the target values that should be used to guide clinical practice in both CD and UC (treat to target approach) [74]. These target values would be a combination of clinical and endoscopic parameters, with biochemical parameters used as an adjunct. As biochemical parameters have gained importance (and high-quality evidence) in the last few years, these recommendations have been criticized and considered to be already obsolete [75].

Item 14

Standardized outcome assessment, through the use of a core outcome set in clinical practice may represent a new advancement in IBD treatment. The use of the International Consortium for Health Outcomes Measurement (ICHOM) Standard Set for IBD is encouraged (EL5).

[Agreement: "Agree" 83.3\%, "Partially agree 5.6\%, "Disagree" $11.1 \%$, round I]

Outcomes measured so far differ both in quality (biochemical, endoscopic, clinical, patient reported) and in measurement method [e.g.. IBDQ and for quality of life (QoL)]. This has resulted in a great heterogeneity in outcome measures in the literature, which in turn translates into considerable difficulty when comparing and analyzing clinical trials [77-78]. All current treatment options, including those recommended in this guideline, have been tested against a number of different outcomes. A core outcome set (COS) is a consensus-derived minimum set of outcomes that should be measured and reported in all clinical trials of a given disease [79, 80].In many diseases, COS, with which physicians evaluate and report the quality of their care, has been developed and implemented with success [80]. In the USA a collaborative has pioneered this methodology on a small scale and reported a significant increase in remission rates in pediatric $\mathrm{CD}$ patients when pre-defined outcomes were reported across the collaboration [73]. For these reasons, it is reasonable to introduce outcome assessment through a COS in IBD, to standardize clinical trials as well as to improve the quality of clinical practice. To date, only one COS has been proposed for IBD care [81], while others are in development. Kim et al. [81] (a team of gastroenterologists, surgeons, specialist nurses, PROM methodology specialists and patients) have produced a consensus identifying four domains which reflected the whole cycle of care for CD and UC: survival and disease control; symptoms, function, and quality of life; disutility of care; and healthcare utilization. Within these domains several outcome measures were chosen to produce the final core set. These include in the short term: overall survival (and cause of death), complication rate, length of hospital stay and quality of life through the IBD control questionnaire. Long-term outcome measures to be added to the previous four include: body mass index (BMI), steroid use, anemia, disease activity through the Manitoba IBD Index (a single-item, patient-defined disease activity measure) [82], diagnosis of colorectal cancer (CRC) and fistula symptoms in CD patients. These should be reported yearly (QoL, Manitoba, anemia every 6 months). A further set of case-mix variables for risk adjustment should be reported only at baseline. No data yet exist to indicate that standardized outcome assessment impacts results of IBD treatment, as these methods have not yet been widely implemented. Nonetheless, results from other specialties are encouraging [72].

The ICHOM standard set does not include many parameters that have been used in various studies in IBD [81]. One outcome that is not present in the ICHOM set is reoperation for disease recurrence. This item is a main factor in assessing and comparing the results of surgical procedures as well as new treatments. Also, various studies have shown that surgery for recurrence carries a substantially higher burden of complications, which become proportionally more frequent with increased number of procedures [83, 84]. Moreover, it is a major source of preoccupation and anxiety for most 
patients with $\mathrm{CD}$. Therefore, the use of reoperation data for outcome assessment is advised.

\section{Neoplasia in IBD}

\section{Small bowel cancer}

Item 15

CD patients have an approximatively 20 -fold increased risk of small bowel adenocarcinoma in Crohn's disease (EL1), which is the most frequent small bowel neoplasia for these patients (EL 3). It usually arises in inflamed areas (EL 5) or segments with long-lasting strictures (EL4).

[Agreement: "Agree" 94.4\%, "Disagree" 5.6\%, round I]

The frequency of small bowel adenocarcinoma is low being approximatively about $2 \%$ of all cancer of the gastrointestinal tract; however, it is significantly increased in $\mathrm{CD}[9,85]$. In a recent meta-analysis of 20 clinical studies including over 40,000 CD patients, the incidence was 0.3/1000 person years duration (CI, 0.1-0.5), which compared to the age-matched background population represents an increase of 18.75 [86]. Interestingly, the same study also reported a significant frequency of cancers arising from CD-associated fistulae $(0.2 / 1000$ person years duration [CI 0.0-0.4]). Possible identified risk factors for small bowel adenocarcinoma include distal jejunal/ileal $\mathrm{CD}$ localization, strictures and chronic penetrating disease, long disease duration, young age at diagnosis, male sex, use of steroids and immunomodulators and small bowel bypass loops [85]. The tumors developed more often in more inflamed areas, and the use of 5-aminosalicylic acid (ASA) for more than 2 years seemed to reduce the risk ( $\mathrm{OR}=0.16, p=0.02)$ [87]. In the large cohort of an Italian Consortium, the overall survival was worse in $\mathrm{CD}$ patients with small bowel adenocarcinoma than in celiac disease patients with these tumors [88].

\section{Cancer associated with fistula in ano}

Item 16

Cancer arising on complex perianal Crohn's fistula tracts, mainly mucinous adenocarcinoma, is rare (EL $1)$.

Substantial risk factors for malignant degeneration are represented by long-standing chronic fistulas (longer than 10 years since onset) and anal stenosis, especially in female patients (EL 2).

[Agreement: "Agree" 100\%, round I] Item 17
In patients with long-standing perianal $\mathrm{CD}$, a change in symptoms, and particularly an unexplained pain, should always raise the suspicion of cancer (EL 2).

Fistula-related cancer presents with non-specific signs and symptoms and is usually at an advanced stage at the time of diagnosis (EL 3).

The gold standard treatment of fistula-associated anal adenocarcinoma in patients with $\mathrm{CD}$ is abdominoperineal resection with or without neoadjuvant chemoradiation, but results in terms of survival are poor (EL 4).

[Agreement: "Agree" 100\%, round I]

Item 18

Regular and careful surveillance for anorectal carcinoma should be recommended for all patients with perianal CD by means of clinical examination (EL5). Frequency and modalities of surveillance are not defined (EL5). Contrast-enhanced MRI should be performed together with clinical examination in all patients with long-standing active perianal disease (EL5). Screening for anal human papilloma virus (HPV) could also be considered (EL5). EAU with biopsy or fistulectomy (excision of fistula tracts) should be recommended in the case of change or worsening in clinical symptoms that is resistant to medical treatment and/or in the presence of any suspicious lesion (EL 5).

[Agreement: "Agree" 94.1\%, "Neutral" 5.9\%, round II]

Cancer associated with perianal fistulas in CD is rare [85, 89]. In a meta-analysis with 40,547 patients, the incidence of fistula-related cancer was $0.2 / 1000$ patient/year [86]. Only four patients had fistula-associated adenocarcinomas in a 17-year follow-up study among 6058 patients with perianal fistulas [90], Occurrence is being increasingly reported [91], and among the total 113 cases described, 52 occurred after 2008 [92]. Mucinous adenocarcinomas are more frequent [93]. Pathogenesis could be associated with local chronic inflammation [94], adenomatous transformation of the epithelium with progression dysplasia-carcinoma or epithelialto-mesenchymal transition within a longstanding fistula [89]; HPV infection [95, 96]; drug-induced immunosuppression [97]; hypoxia [98]. Immunomodulation could play a key role in the progression from chronic inflammation left in situ to carcinoma [99]. Long-standing perianal $\mathrm{CD}$ (>10 years) is considered to be the main risk factor together with anal stenosis. Symptoms and signs are non-specific, and clinical examination is usually limited by pain, stricture, and/ or induration of perineal tissues [100]. Typically, patients present worsening of symptoms, such as increased discharge and/or pain, in spite of medical or surgical treatment [101]. All these factors complicate and delay diagnosis, worsening the prognosis at diagnosis for advanced stage cancer [85, 102, 103]. The gold standard treatment is abdominoperineal 
resection with/without neoadjuvant chemoradiation vs. radiation or chemoradiation alone. A rate of local recurrence of $30 \%$ after abdominoperineal excision versus $40 \%$ after radiation therapy is reported with survival rates of $62 \%$ and $60 \%$, respectively [104]. Complete response after neoadjuvant chemoradiation therapy followed by abdominoperineal excision is described [105].

Optimal frequency and modalities of surveillance to detect premalignant lesions and early anorectal cancers are not well defined. Ogawa et al. suggested that patients should undergo surveillance after 7 years of perianal disease [106]. Regular surveillance should be requested for all patients with perianal CD using perianal clinical examination, including digital rectal examination. EUA with biopsy should be recommended in case of any change or worsening in clinical symptoms resistant to medical treatment and/or in the presence of any suspicious lesion $[9,93]$.

\section{Colorectal cancer}

Item 19

There is at least a twofold increased risk of CRC in UC and Crohn's colitis compared with the general population. Risk (mainly for UC) is associated with disease duration (EL 2), disease extent (EL 2), and inflammatory activity (EL 2) and is further increased in case of family history for colon cancer (EL 3) or concomitant primary sclerosing cholangitis.

[Agreement: "Agree" 94.4\%, "Disagree" 5.6\%, round I]

Item 20

Screening colonoscopy should start 8 years following the onset of symptoms with the aim of ruling out dysplasia (EL 5) or early detection of colon cancer which leads to an improved prognosis and survival (EL 3). The timing of endoscopic surveillance is not clearly defined and should be better tailored on the basis of underlying risk factors (EL5).

[Agreement: "Agree" 83.3\%, "Neutral" 5.6\%, "Disagree" $11.1 \%$, round I]

The risk of CRC seems to be reduced over time, following the previous alarming meta-analysis of Eaden et al. in 2001, and this is probably due to a better control of disease activity and the activation of program of screening and surveillance [107]. However, two recent meta-analyses of population-based cohorts $[108,109]$ have estimated an excess standardized incidence ratio (SIR) of 2.4, with increased risk for young age at diagnosis $(\mathrm{SIR}=8.6)$, and extensive colitis $(S I R=4.8)$. Other important risk factors are a family history of CRC and primary sclerosing cholangitis, particularly in UC. The CRC cancer risk is at
1.9 for CD. Of note, IBD patients tend to develop CRC at younger ages than non-IBD patients and with a more aggressive course.

Surveillance colonoscopy programs reduce morbidity and mortality due to CRC by detecting cancer at an earlier stage with better prognosis or by detecting and resecting dysplasia, reducing CRC incidence [9]. The benefit estimated in years of life saved may be much greater in colitis patients than for general population screening, because IBD-CRC tends to occur earlier in life and modeling studies have shown that life saved per case screened ranges from 1.2 to 5 years in UC patients, compared to 1.2-4 months in general population screening $[9,110,111]$. Disease duration is a major risk factor for the development of IBD-CRC, hence, screening colonoscopy should be recommended when the risk starts to increase (i.e., 8-10 years after the onset of disease). This colonoscopy assesses the extent of disease. The timing of dysplasia progression is not known in IBD. Therefore, intervals between repeat surveillance colonoscopy should be prospectively adjusted to each patient taking into consideration CRC risk factors and previous endoscopic findings [2, 9].

Pouch-related adenocarcinoma is extremely rare, the risk being much lower than in the general population $[112,113]$.

\section{Dysplasia in IBD}

Item 21

Dysplasia and CRC in IBD are strictly related to the duration and extension of the disease, grade of inflammation, young age, and family history of CRC (EL4). The presence of primary sclerosing cholangitis increases the risk of colorectal cancer in ulcerative colitis.

[Agreement: "Agree" 94.1\%, "Partially agree" 5.9\%, round II]

The risk of developing dysplasia and CRC in the context of IBD increases in relation to several factors, including duration and extension of the disease, microscopic intensity of inflammation, young age of onset and family history of $\mathrm{CRC}$, especially if there is a first degree relative diagnosed with CRC before the age of 50 years [115-116]. Small bowel involvement is a specific risk factor for $\mathrm{CD}$, while the presence of primary sclerosing cholangitis increases the risk of CRC only in UC [115-116].

Item 22

TP53 mutation is the key factor in IBD-associated carcinogenesis. CRC related to IBD may also follow the serrated pathway versus neoplasia, associated with alteration of deoxyribonucleic acid (DNA) repair mechanisms (EL2).

[Agreement: "Agree" 94.1\%, "Neutral" 5.9\%, round II] 
In CRC associated with IBD, mutations are similar to those of sporadic forms, but differ in order and frequency: the functional loss of APC occurs less frequently and usually in later stages, while TP53 is the key factor in IBDassociated carcinogenesis [118-121].

As in sporadic forms, CRC related to IBD may also follow the serrated pathway versus neoplasia, i.e., a hyperplastic polyp, sessile serrated polyp without dysplasia and traditional adenoma. These tumors are associated with alteration of DNA repair mechanisms that induce microsatellite instability and are related to BRAF mutation [118-121].

Item 23

Dysplasia is distinguished endoscopically as visible and invisible. The visible lesions are subdivided into polypoid, if the lesion protrudes in the lumen for more than $2.5 \mathrm{~mm}$, and not polypoid, when the lesion is not protruding or protruding into the lumen for less than $2.5 \mathrm{~mm}$ (EL2).

[Agreement: "Agree" 100\%, round II]

Item 24

Dysplasia is divided into four categories: negative for neoplasia, low-grade, high-grade, undefined for dysplasia. The presence of inflammation and regenerative/ reparative changes of the epithelium make it difficult to identify true atypia: the second opinion of an IBD expert pathologist is recommended (EL3).

[Agreement: "Agree" 94.1\%, "Partially agree" 5.9\%, round II]

From an endoscopic point of view, dysplasia is distinguished as visible and invisible, defined as dysplasia identified on random biopsies performed on apparently healthy mucosa $[122,123]$. The visible lesions are further subdivided into polypoid, if the lesion protrudes in the lumen for more than $2.5 \mathrm{~mm}$, and not polypoid, when the lesion is not protruding or protruding in the lumen for less than $2.5 \mathrm{~mm}$. The lesions can also have distinct or indistinct edges and can be ulcerated [122, 123].

Four categories of dysplasia can be identified at pathology: negative for neoplasia, low-grade non-invasive neoplasia, high-grade non-invasive neoplasia and undefined neoplasia/dysplasia [124, 125].

In the context of IBD, the presence of inflammation and regenerative and reparative changes of the epithelium make it difficult to identify true atypia. In these situations, the "undefined neoplasm" diagnostic category is used, but the second opinion of an IBD expert pathologist is recommended [124, 125].

Item 25

Visible polypoid or non-polypoid lesions can be resected with endoscopic excision when the margins are endoscopically recognizable and the biopsies of the adjacent mucosa do not show dysplasia. In the case of invisible high-grade lesions, colectomy is recommended (EL2).

[Agreement: "Agree" 94.1\%, "Neutral" 5.9\%, round II]

The lesions are divided into resectable and unresectable: when the margins are endoscopically recognizable and the biopsies of the adjacent mucosa do not show dysplasia, the lesion is defined resectable. When a resectable visible lesion of the polypoid or non-polypoid type is detected, endoscopic excision may be performed. If the margins of the lesion are barely recognizable, the lesion is considered unresectable and the therapeutic option should be colectomy [123, 126].

For endoscopically invisible lesions, it is recommended to contact experienced IBD endoscopists to assess the possible presence of well-defined, and therefore resectable, lesions and possible synchronous lesions. If an invisible lesion has indefinite margins, the therapeutic choice depends on the degree of dysplasia [123, 126]. In the case of invisible highgrade lesions, colectomy is recommended, although it is possible to perform an endoscopic resection in the absence of outbreaks of dysplasia in the surrounding mucosa, followed however by close endoscopic surveillance [123, 126]. The natural history of low-grade invisible lesions is unclear and therapeutic strategies differ among centers [123, 126].

\section{Intestinal failure in IBD}

\section{Risk factors and assessment in IBD}

\section{Item 26}

The risk factors for intestinal failure in IBD are surgery, especially in case of repeated or extended resection (EL3), and aggressive bowel disease, which is related to disease behavior and young age (EL4). [Agreement: "Agree" 88.2\%, "Partially agree" 11.8\%, round $\mathrm{II}]$

Item 27

The assessment of intestinal failure requires specialist multidisciplinary management and is mainly based on serial body weight/BMI measurements, self-screening strategies and laboratory studies (EL3). The role of new biomarkers should be clarified.

[Agreement: "Agree" 94.1\%, "Partially agree" 5.9\%, round $\mathrm{II}]$

Intestinal failure (IF) is defined by the ESPEN group [127] as "the reduction of gut function below the minimum necessary for the absorption of macronutrients and/or water and electrolytes, such that intravenous supplementation is required to maintain health and/or growth"; it is possible to functionally differentiate between acute intestinal failure 
(short-term and prolonged acute) and chronic intestinal failure (CIF). CD is one of the most common underlying conditions, especially in CIF (22.4\%), and short bowel syndrome (SBS) is the most frequent pathophysiological mechanism due to surgery or aggressive disease [128].Thus, IF risk factors could be related to surgery, such as repeated or extended resection (especially where remaining small intestine is $<200 \mathrm{~cm}$ ) [129], ostomy creation [129], and perioperative complications [130] or related to disease, such as behavior (penetrating or stricturing) $[129,130]$ and young age at diagnosis or at surgery [130].

Further studies are required to clarify the role of smoking, a family history of IBD and the effect of medical therapy [131]. Bowel-sparing surgery plays a key role in preventing SBS [132].

The assessment of IF should begin with an attentive appraisal of the patiemt's nutritional status and its optimization, and this is paramount in surgical patients because it is strongly related to the patient's outcome [46, 133, 134]. The assessment of nutritional status requires multidisciplinary management with the active participation of the dietitian [135] and involves several factors such as serial body weight/ BMI measurements, self-screening strategies [Malnutrition Universal Self-Screening Tool (MUST)] [136] and laboratory studies (albumin, iron and micronutrient levels) [139], although these tests can be influenced by the CD-related systemic inflammatory response. In this setting, further studies are required to establish the validity of biomarkers of IF, such as serum citrulline [137] and intestinal fatty acid binding protein [138].

Item 28

IF is an uncommon condition (50 per million people with CIF) that may result from obstruction, dysmotility, surgical resections, congenital defects or diseaseassociated loss of absorption and characterized by the inability to maintain protein-energy, fluid, electrolyte or micronutrient balance (EL2).

In $\mathrm{CD}$, extensive surgical resections, surgery for complications (EL3) and aggressive small bowel disease (EL4) are the most common causes of SBS and are thus risk factors for IF.

[Agreement: "Agree" 100\%, round II]

IF is a debilitating condition characterized by inability to maintain a state of adequate nutrition and/or fluid and electrolyte balance, because of an anatomical and/or physiological disorder of the intestine and can be caused by five major pathophysiological conditions such as extensive resections, intestinal fistula, intestinal dysmotility, mechanical obstruction, congenital defects and extensive small bowel mucosal disease. $\mathrm{CD}$ is among the leading causes of intestinal failure, second only to cancer patients (11-17\% vs $29-41 \%)$ [139, 140].Three categories exist [141]: type 1 generally occurs postoperatively and is self-limiting, such as patients developing ileus, requiring short-term parenteral nutritional (PN) support for days or weeks. Type 2 most commonly develops in individuals with abdominal or generalized sepsis following major complicated intestinal resection. Patients require PN for many weeks or months. Type 3 is irreversible, and long-term home parenteral nutrition (HPN) is required. CD is most commonly associated with type 3 , but the overall incidence is low. The prevalence of type 3 IF as a percentage of all causes is estimated to be 3\% in UC and $29 \%$ in CD [142]. UC is rarely associated with type 3 IF because the small intestine is uninvolved, but IF can still occur after perioperative complications. When IF occurs in patients with $\mathrm{CD}$, it is usually due to complications of surgery for intra-abdominal sepsis, extensive primary small bowel disease impairing nutrient absorption, or extensive resection leading to SBS. The first one is the principal cause of IF in CD [127]. Predisposing factors to type 3 IF include: younger age at diagnosis and at first operation, stricturing disease or family history of inflammatory bowel disease [143]. Anatomical classification of SBS is also important, with three different groups [144]:

- Group I: with an end jejunostomy, chronic IF is generally observed if $<1 \mathrm{~m}$ of small bowel remains.

- Group II: with jejuno-colonic anastomosis, chronic IF is generally observed if $<0.5 \mathrm{~m}$ of the small bowel remains with all the colon in place.

- Group III: with jejuno-ileo anastomosis and preservation of the ileocecal junction; this is the "best case" for which only $30-50 \mathrm{~cm}$ of small bowel remaining is enough to avoid (chronic) IF.

\section{Principles for the management of IF in IBD}

Item 29

Preoperative optimization of the patients, reduction of postoperative complications and bowel-sparing techniques, such as strictureplasty and minimal small bowel resections, all lead to a decreased risk of short bowel syndrome, thus decreasing the risk of intestinal failure (EL2).

[Agreement: "Agree" 94.1\%, "Partially agree" 5.9\%, round II]

Item 30

Management of IF requires a multimodal approach, not only in the short term but also in the long term, including support for home-based treatment (EL3). In type IIIF, sepsis must be investigated and treated, nutritional support must be provided, a minimum length of small bowel must be preserved and a long-term plan discussed in a multidisciplinary team (EL4).

[Agreement: "Agree" 100\%, round II] 
Item 31

Home parenteral nutrition should continue to be the primary therapeutic option for IF due to better or comparable long-term survival compared with intestinal transplantation (EL5). Although patient survival rates after intestinal transplantation continue to improve, the risk of developing major complications is still relevant, thus suggesting that intestinal transplantation has a role as a potential life-saving intervention, particularly in patients with difficult venous access or abnormal liver function (EL5).

[Agreement: "Agree" 94.1\%, "Partially agree" 5.9\%, round II]

Adapted from Vaizey et al. [144]. Surgical management of patients with IF requires expertise in terms of technical challenges and decision-making. Adequate surgical strategies must be used to avoid IF in CD patients. Patients with $\mathrm{CD}$ are at $5-10 \%$ risk of developing SBS due to repetitive surgical procedures, surgery for complications, wrong preoperative diagnosis and penetrating small bowel disease. The major risk factor for developing chronic IF in patients with CD is the severity of the small bowel disease, rather than surgical procedures. To reduce surgical complications and avoid this chronic condition, preoperative optimization of the patients, good nutritional status, minimally invasive surgery, and bowel-sparing techniques (strictureplasty or minimal small bowel resections) are recommended [145].

\section{IBD in adolescents and transition. IBD in the elderly}

\section{Critical issues in early-onset IBD}

Item 32

CD surgery must be limited to a localized intestinal segment in case of small bowel or colonic symptomatic disease not responsive to medical treatment in pediatric patients (EL2). Strictureplasty should be strongly considered as the first step of surgical management even in case of extended intestinal CD (EL4). [Agreement: "Agree" 94.1\%, "Partially agree" 5.9\%, round II]

In case of a localized intestinal disease, a limited resection must be preferred to reduce the risk of short bowel syndrome in long-term follow-up [146, 147]. There are few studies in literature on strictureplasty for $\mathrm{CD}$ in pediatric patients [148]. Compared to intestinal resection, strictureplasty allows intestinal length with the same relapse rate [152]; however, few data are available concerning the outcome of strictureplasties in children. An in-depth discussion of the topic was beyond the scope of this manuscript. The reader is advised to consult specialized reviews for further information.

Item 33

CD complex perianal fistulae in pediatric patients should be treated with noncutting seton placement as first-line treatment (EL2). Fistulectomy combined with medical treatment can be considered an alternative to stoma diversion in case of complex perianal treatment refractory to medical therapy and seton placement. (EL4).

[Agreement: "Agree" 94.1\%, "Partially agree" 5.9\%, round II]

The ECCO/ESPGHAN guidelines [147, 149] reported that combined medical therapy with seton placement was the gold standard treatment for complex perianal fistulae.

A NASPGHAN study on perianal fistulae management reports an increased risk of sphincteric lesion following cutting seton placement [150]. The choice of stoma diversion or fistulotomy is a controversial argument in cases of perianal complex fistulae refractory to medical therapy and seton placement. In CD the restoration rate of intestinal continuity after a stoma diversion is relatively low [151]. There is a lack of comparative studies between stoma diversion and fistulectomy. A novel technique associating endorectal pull-through and fistulectomy [152] allows reduction of the stoma diversion rate, with a low incidence of complications.

\section{Item 34}

CD laparoscopic resection should be considered an ideal approach in case of localized intestinal disease in pediatric patients (EL1).

[Agreement: "Agree" 94.1\%, "Partially agree" 5.9\%, round II]

Minimally invasive surgery for pediatric CD is under debate. Several case series and case-control studies showed many advantages in terms of pain management and reduced length of hospital stay $[153,154]$. Despite these results, to date there is a lack of strong studies comparing laparoscopic versus open techniques in the pediatric population.

Item 35

UC elective colectomy should be performed in case of active ulcerative colitis and growth retardation despite maximal medical therapy in pediatric patients (EL2). Ileal J-pouch-anal anastomosis should be offered to restore intestinal continuity (EL2).

[Agreement: "Agree" 94.1\%, "Partially agree" 5.9\%, round II]

In case of steroid-dependent patients with active disease while on infliximab and immunomodulatory treatments, elective colectomy should be performed to allow clinical 
control of the patient [155]. Historical patient exposure to anti-TNFs with absence of endoscopic mucosal healing and absence of response after biological treatment at induction are both predictive factors of colectomy. Ileal j-pouch-anal anastomosis despite the risk of postoperative pouchitis has proven to be superior to straight ileo-anal pull-through in terms of fecal continence, stool frequency and perianal sepsis [156]. Two-stage surgical management (colectomy then proctectomy with ileal J-pouch-anal anastomosis) should be preferred to a one-stage procedure because of the lower complication rate; three-stage surgical management should be preferred in case of patients with malnutrition and worse clinical conditions $[4,157,158]$. Colectomy is as effective as immunosuppressants for allowing "catch-up" in growth status in children with growth retardation [159].

Item 36

UC minimally invasive surgery should be considered the gold standard for colectomy and ileal J-pouch-anal anastomosis (EL2).

[Agreement: "Agree" 94.1\%, "Partially agree" 5.9\%, round II]

Over the years, laparoscopic colectomy and ileal $\mathrm{j}$-pouch-anal anastomosis have been reported as safe and feasible procedures in children [160], with better outcomes in terms of complication rate when compared to the open approaches [161].

\section{Transition of care}

Item 37

Patient should be prepared at least 1 year before the transition (EL4). The transition process should be coordinated by a specialist pediatric nurse (EL4). [Agreement: "Agree" 88.9\%, "Neutral" 11.1\%, round I]

Item 38

Patients with IBD should actively participate in the transition of care process (EL4). Self-assessment scale can evaluate patient progression during transition (EL4).

[Agreement: "Agree" 100\%, round II]

An adequate preparation is needed before the transition with a minimum advance of 12 months to favor the patient's independent behavior and knowledge of the disease [162]. A transition coordinator, usually a specialist IBD nurse, can help to overcome the gap between pediatric and adult teams [163, 164].

Patients who are actively involved in a transitional program have better outcome in terms of attendance at clinics, drug compliance and hospital admission rate than those who are not involved, optimizing health-care resources
[165]. Self-management analysis (also called self-efficacy) is a behavior tool to improve quality of life that was just reported in pediatric chronic diseases as type 1 diabetes mellitus [166]. A multiple items disease-specific scale has been reported to assess the patient's progression during transition, to monitor self- management and patient knowledge $[167,168]$.

\section{IBD in the elderly}

\section{Item 39}

Elderly IBD patients can be divided into two groups: individuals diagnosed at a younger age who attain an elderly age and those first diagnosed at or after age 60 years. New IBD diagnosis in elderly takes longer and misdiagnosis is quite common (EL3).

[Agreement: "Agree" 94.12\%, "Neutral" 5.9\%, round II]

The proportion of patients with elderly onset IBD varies from 3 to $21 \%$ for CD and 7 to $29 \%$ for UC [169]. Elderly patients with long-standing IBD who were diagnosed in younger adulthood may be clinically distinct from those with elderly onset IBD [170].

Compared to younger adults, the initial diagnosis of IBD in the elderly is generally more difficult and consequently takes longer. The differential diagnosis of IBD in the elderly includes infectious colitis, ischemic bowel disease, segmental diverticulitis, NSAID enteropathy, malignancy, microscopic colitis, radiation enteritis and solitary rectal ulcer syndrome. Moreover, the presentation of IBD can be more subtle in seniors. On average, there is a delay in diagnosis of up to 6 years in the elderly compared to 2 years in younger adults $[171,172]$.

A family history of IBD and the prevalence of extraintestinal manifestations are less common in elderly onset IBD patients [173].

Age-related changes in immune function and the gut microbiome may increase susceptibility to infections, making chronic immunosuppressive therapy in the elderly population less than ideal [174]. In addition, treatments that require frequent laboratory monitoring or regular trips to infusion centers may be more challenging for older patients due to logistical considerations $[174,175]$.

Item 40

Elderly CD patients appear to have higher rates of isolated colonic disease and disease behavior with less penetrating complications or perianal disease. Patients with older-onset UC have more frequent left-sided disease compared to younger IBD cohorts (EL3).

[Agreement: "Agree" 100\%, round I] 
Late-onset IBD differs from early onset in many aspects, including location and phenotype of the disease at diagnosis, symptoms at presentation and natural disease progression [174]. Elderly CD patients typically present with colonic involvement (L2 in the Montreal classification) and inflammatory disease behavior (B1), with less frequency of fistula or stricture development compared to younger patients [176]. Further, disease behavior or phenotype in CD does not typically change among the elderly. Elderly UC patients experience more commonly left-sided colitis, while extensive disease and isolated proctitis are proportionally less frequent than in adults $[176,177]$.

The clinical presentation of UC may be subtle, with less reports of bleeding, diarrhea, or pain, but often the first flare is more severe [176]. Usually, those who remain surgery free after the first flare of disease are more likely to have a more benign disease prognosis in the long term [178].

\section{Item 41}

Treatment of IBD in the elderly is complicated by the presence of comorbidities and by the risk of drug interactions, which is exacerbated by polypharmacy. UC elderly onset patients seem to be more likely to undergo surgery, whereas the overall surgery rates between young and elderly patients with $\mathrm{CD}$ diagnosed early are similar (EL3).

\section{[Agreement: "Agree" 100\%, round I]}

Comorbid health conditions such as heart disease, diabetes, cancer, psychiatric disorders and arthritis are commonly present in elderly patients with IBD [170, 171, 179]. Polypharmacy has the potential to increase the risk of drug interactions, and drugs used in the treatment of IBD may contribute to either triggering or worsening concomitant diseases [171].

The choice of the most appropriate therapeutic approach in older patients should be driven by balancing potential benefits and risks on an individual basis. Treatment goals in older IBD patients may focus on immediate symptom relief and improvement of physical functioning to maintain independence, very different from the goals of younger cohorts who may prioritize prevention of long-term disease-related complications [174].

The rates of surgical interventions appear to be higher in older-onset than younger-onset UC at years 1 and 5 after diagnosis, but similar in older-onset CD compared with younger-onset disease [171]. It is unclear whether higher rates of surgery are driven by a less benign natural disease course in older-onset disease, reluctance of physicians to employ immunomodulators, aggressive treatment regimen in elderly patients or complications due to comorbid conditions $[174,175]$.

In general, elderly patients with IBD are at substantially higher risk of postoperative complications (especially infections and venous thromboembolism) and mortality, particularly in an emergency setting $[170,177,180,181]$.

The risk of CRC in IBD increases with increasing disease duration, positive family history of IBD, primary sclerosing cholangitis and prolonged and persistent mucosal inflammation [173]. Elderly onset IBD itself is not associated with an additional increased risk of colorectal cancer. CRC screening in the elderly should be balanced with disease severity, comorbidities and life expectancy [177].

A large French cross-sectional study of IBD patients suggests that older age ( $>60$ years) is not associated with worse quality of life, fatigue or disability [182].

\section{Patient-reported outcome measures in IBD}

\section{PROMs available for IBD assessment}

\section{Item 42}

A moderate to strong correlation between rectal bleeding and stool frequency, and endoscopic activity has been reported in UC patients (EL4). PRO-2 and -3 scale derived from CDAI diary items may be appropriate for use in clinical trials for CD (EL4).

Current evidence is not sufficient to recommend the use of available PROMs in IBD, which have to be validated before introduction in clinical practice (EL5). [Agreement: "Agree" 83.2\%, "Partially agree" 5.6\%, "Neutral" 5.6\%," Disagree" 5.6\%, round I]

Medically reported activity indexes are generally used to provide disease activity monitoring. Patient-reported outcome measures (PROMs) are important determinants of the illness experience, particularly from a patient's point of view. In the era of an increasing IBD incidence with limited health-care resources, as an alternative, PROMs may help clinicians to improve follow-up strategies [183, 184]. Furthermore, The US Food and Drug Administration has indicated that patient-reported outcomes (PROs) should be the primary outcome in randomized controlled trials for CD [68].

In a recent meta-analysis, including mostly observational studies, a moderate to strong correlation between clinical activity, particularly the combination of rectal bleeding and stool frequency, and endoscopic activity in patients with UC has been shown [185]. These findings could help in prioritizing endoscopic evaluation in resource-limited areas and poor clinical follow-up assessment. However, the studies considered in the above-mentioned report were at moderate-high risk of bias.

As no validated PROMs exist for CD, CDAI diary card items have been investigated to be modified for this purpose. In a retrospective analysis, PRO-2 (abdominal pain, stool 
frequency) and PRO-3 (abdominal pain, stool frequency, and general well-being) were selected from the CDAI diary cards. Scores using the two- and three-item PROs were found to positively correlate to CDAI thresholds of mild, moderate and severe disease [186].

\section{Role of patient and public participation and engagement in IBD research}

Item 43

Prioritizing the outcome relevant to patients, securely sharing data while ensuring privacy and including them in the evolving research beyond an initial enrollment, is likely to improve adherence to recommendations and patient quality of life (EL5).

[Agreement: "Agree" 94.4\%," Disagree" 5.6\%, round I]

Patient perspectives are crucial for the development of guidelines on therapeutic management of IBD. The objective of increased patient participation in IBD research must be to prevent the disease and its complications, to seek innovative treatments and to access new therapeutic options, improving the patients' quality of life and society's awareness of the disease [187]. To do so, it is necessary to break down barriers related to the levels of security and confidentiality of the processed data, the limited resources made available, the uncertainty of how to integrate patients' experiences into evidence-based guidelines, the time required for each individual patient and the use of a language not always accessible to all [188]. The possibility of easier updates on the progress of research and a greater communication between patients and researchers would make it possible to understand the disease from the patient's point of view [189]. This knowledge could be used to question epistemic assumptions in medical research practices and to increase the centrality of the patient within the health-care system in general [190]. The patient's experience is an additional perspective to the one of researchers and medical staff.

\section{Future directions}

\section{Dedicated IBD training}

Item 44

Subspecialty training in IBD surgery should take place within established high-volume multidisciplinary IBD units (EL4). IBD surgery training should include minimally invasive surgery techniques (EL3)

[Agreement: "Agree" 100\%, round II]
The technical expertise required to operate on complex $\mathrm{CD}$ and $\mathrm{UC}$, and the perioperative decision making about when to operate and whether to fashion an anastomosis or to create a stoma, require highly trained surgeons [191]. Increased experience with individualized management has demonstrated a reduction in the complications rate for patients who undergo colectomy for ulcerative colitis [192], and experience with the management of complications may lead to a higher rate of ileal pouch salvage after anastomotic leak [193].

Considering the complexity of the management of the IBD patient, surgeons in training should be exposed to effective subspecialized multidisciplinary care working in specialized IBD units [4, 8, 194, 195], collaborating as a team to optimize the integration of medical management and surgery and provide tailored and best evidence-based management for the individual IBD patients [43, 197-198].

Although several aspects of IBD like a thickened and friable mesentery, enteric fistulas, bowel perforation and intra-abdominal abscesses and adhesions make laparoscopic surgery technically demanding [199], the rate of laparoscopically managed complex IBD procedures is increasing [200]. Supervised training programs have been demonstrated to significantly decrease the length of the learning curve [201] and laparoscopic IBD surgery can be safely performed by surgical trainees in a supervised setting [202], even in the setting of complex and reoperative surgery [203].

\section{Conclusions}

The committee felt that several aspects of the general principles of management of CD and UC need further investigation.

These include the perioperative disease assessment, patient-reported outcome measures and quality of life tools specific for IBD, dedicated training, and patient participation in clinical decision making and research planning. Also, IBD in the elderly seems not to have received enough attention.

Future studies should assess these aspects.

The resulting recommendations are to be intended as a suggested pathway to follow, but they need to be applied carefully, after taking into account the individual features of each patient, and after a clear discussion with the patient about all the available options for each specific condition, and realistic expectations.

Acknowledgements The authors would like to thank Ms. Marina Fiorino, secretary of the SICCR, for her help during the development of the project. The authors and SICCR are grateful to Salvatore Leone for participating on behalf of the "Associazione nazionale per le Malattie Infiammatorie Croniche dell'Intestino" (Italian National Association for Inflammatory Bowel Diseases) "A.M.I.C.I. Onlus" as patient representative in project designing and delivering. 
Collaborators: Remo Andreoli, Imerio Angriman, Paola Caprino, Mattia Facchetti, Gaetano Luglio, Gilberto Poggioli, Gianluca Rizzo, Giulia Roda, Matteo Rottoli, Franco Sacchetti, Bruno Sensi, Luigi Sofo.

Steering Committee: Gianluca Pellino (coordinator), Deborah S. Keller (external advisor), Gianluca M. Sampietro (coordinator), Salvatore Leone (patient representative), Silvio Danese (external expert), Antonino Spinelli (leader), GianGaetano Delaini (SICCR IBD Committee Chair, leader), Francesco Selvaggi (SICCR President, leader).

\section{Funding None.}

\section{Compliance with ethical standards}

Conflict of interest The authors declare that they have no conflict of interests.

Ethical approval The present paper was exempt from approval.

Informed consent Informed consent was not needed for this study. No procedures on patients were performed by the authors for this study.

\section{References}

1. Gionchetti P, Dignass A, Danese S, Magro Dias FJ, Rogler G, Lakatos PL, Adamina M, Ardizzone S, Buskens CJ, Sebastian S, Laureti S, Sampietro GM, Vucelic B, van der Woude CJ, Barreiro-de Acosta M, Maaser C, Portela F, Vavricka SR, Gomollón F, ECCO (2017) 3rd European Evidence-based consensus on the diagnosis and management of Crohn's disease 2016: part 2: surgical management and special situations. J Crohn's Colitis 11(2):135-149. https://doi.org/10.1093/ecco-jcc/jjw169

2. Magro F, Gionchetti P, Eliakim R, Ardizzone S, Armuzzi A, Barreiro-de Acosta M, Burisch J, Gecse KB, Hart AL, Hindryckx P, Langner C, Limdi JK, Pellino G, Zagórowicz E, Raine T, Harbord M, Rieder F, [ECCO] ECsaCO (2017) Third European evidence-based consensus on diagnosis and management of ulcerative colitis: part 1: definitions, diagnosis, extra-intestinal manifestations, pregnancy, cancer surveillance, surgery, and ileoanal pouch disorders. J Crohn's Colitis 11(6):649-670. https:// doi.org/10.1093/ecco-jcc/jjx008

3. Magro F, Peyrin-Biroulet L, Sokol H, Aldeger X, Costa A, Higgins PD, Joyce JC, Katsanos KH, Lopez A, de Xaxars TM, Toader E, Beaugerie L (2014) Extra-intestinal malignancies in inflammatory bowel disease: results of the 3rd ECCO Pathogenesis Scientific Workshop (III). J Crohn's Colitis 8(1):31-44. https ://doi.org/10.1016/j.crohns.2013.04.006

4. Øresland T, Bemelman WA, Sampietro GM, Spinelli A, Windsor A, Ferrante M, Marteau P, Zmora O, Kotze PG, Espin-Basany E, Tiret E, Sica G, Panis Y, Faerden AE, Biancone L, Angriman I, Serclova Z, de Buck-van-Overstraeten A, Gionchetti P, Stassen L, Warusavitarne J, Adamina M, Dignass A, Eliakim R, Magro F, D'Hoore A (2015) European evidence based consensus on surgery for ulcerative colitis. J Crohn's Colitis 9(1):4-25. https ://doi.org/10.1016/j.crohns.2014.08.012

5. Rieder F, de Bruyn JR, Pham BT, Katsanos K, Annese V, Higgins PD, Magro F, Dotan I (2014) Results of the 4th scientific workshop of the ECCO (group II): markers of intestinal fibrosis in inflammatory bowel disease. J Crohn's Colitis 8(10):1166-1178. https://doi.org/10.1016/j.crohns.2014.03.009

6. Rieder F, Latella G, Magro F, Yuksel ES, Higgins PD, Di Sabatino A, de Bruyn JR, Rimola J, Brito J, Bettenworth D, Van Assche G,
Bemelman W, D'Hoore A, Pellino G, Dignass AU (2016) European Crohn's and colitis organisation topical review on prediction, diagnosis and management of fibrostenosing Crohn's disease. J Crohn's Colitis. https://doi.org/10.1093/ecco-jcc/jjw055

7. van der Woude CJ, Ardizzone S, Bengtson MB, Fiorino G, Fraser G, Katsanos K, Kolacek S, Juillerat P, Mulders AG, Pedersen N, Selinger C, Sebastian S, Sturm A, Zelinkova Z, Magro F, (ECCO) ftECsaCO (2014) The second European evidenced-based consensus on reproduction and pregnancy in inflammatory bowel disease. J Crohn's Colitis. https://doi.org/10.1093/ecco-jcc/jju006

8. Brown SR, Fearnhead NS, Faiz OD, Abercrombie JF, Acheson AG, Arnott RG, Clark SK, Clifford S, Davies RJ, Davies MM, Douie WJP, Dunlop MG, Epstein JC, Evans MD, George BD, Guy RJ, Hargest R, Hawthorne AB, Hill J, Hughes GW, Limdi JK, Maxwell-Armstrong CA, O'Connell PR, Pinkney TD, Pipe J, Sagar PM, Singh B, Soop M, Terry H, Torkington J, Verjee A, Walsh CJ, Warusavitarne JH, Williams AB, Williams GL, Wilson RG, Collaboration AISC (2018) The Association of coloproctology of Great Britain and Ireland consensus guidelines in surgery for inflammatory bowel disease. Colorectal Dis 20(Suppl 8):3-117. https://doi.org/10.1111/codi.14448

9. Annese V, Beaugerie L, Egan L, Biancone L, Bolling C, Brandts C, Dierickx D, Dummer R, Fiorino G, Gornet JM, Higgins P, Katsanos KH, Nissen L, Pellino G, Rogler G, Scaldaferri F, Szymanska E, Eliakim R, ECCO (2015) European evidence-based consensus: inflammatory bowel disease and malignancies. J Crohn's Colitis. https://doi.org/10.1093/ecco-jcc/jjv141

10. Annese V, Daperno M, Rutter MD, Amiot A, Bossuyt P, East J, Ferrante M, Goetz M, Katsanos KH, Kiesslich R, Ordas I, Repici A, Rosa B, Sebastian S, Kucharzik T, Eliakim R, ECCO (2013) European evidence based consensus for endoscopy in inflammatory bowel disease. J Crohns Colitis 7(12):982-1018. https://doi. org/10.1016/j.crohns.2013.09.016

11. Gomollón F, Dignass A, Annese V, Tilg H, Van Assche G, Lindsay JO, Peyrin-Biroulet L, Cullen GJ, Daperno M, Kucharzik T, Rieder F, Almer S, Armuzzi A, Harbord M, Langhorst J, Sans M, Chowers Y, Fiorino G, Juillerat P, Mantzaris GJ, Rizzello F, Vavricka S, Gionchetti P, ECCO (2017) 3rd European evidencebased consensus on the diagnosis and management of Crohn's disease 2016: part 1: diagnosis and medical management. J Crohn's Colitis 11(1):3-25. https://doi.org/10.1093/ecco-jcc/jjw168

12. Torres J, Bonovas S, Doherty G, Kucharzik T, Gisbert JP, Raine T, Adamina M, Armuzzi A, Bachmann O, Bager P, Biancone L, Bokemeyer B, Bossuyt P, Burisch J, Collins P, El-Hussuna A, Ellul P, Frei-Lanter C, Furfaro F, Gingert C, Gionchetti P, Gomollon F, González-Lorenzo M, Gordon H, Hlavaty T, Juillerat P, Katsanos K, Kopylov U, Krustins E, Lytras T, Maaser C, Magro F, Marshall JK, Myrelid P, Pellino G, Rosa I, Sabino J, Savarino E, Spinelli A, Stassen L, Uzzan M, Vavricka S, Verstockt B, Warusavitarne J, Zmora O, Fiorino G (2019) ECCO guidelines on therapeutics in Crohn's disease: medical treatment. J Crohn's Colitis. https://doi.org/10.1093/ecco-jcc/jjz180

13. Pellino G, Keller DS, Sampietro GM, Annese V, Carvello M, Celentano V, Coco C, Colombo F, Cracco N, Di Candido F, Franceschi M, Laureti S, Mattioli G, Pio L, Sciaudone G, Sica G, Villanacci V, Zinicola R, Leone S, Danese S, Spinelli A, Delaini G, Selvaggi F, on behalf of The Italian Society of Colorectal Surgery SICCR (2019) Inflammatory bowel disease position statement of the Italian Society of Colorectal Surgery (SICCR): Crohn's disease. Techs Coloproctol. https://doi.org/10.1007/ s10151-019-02145-0

14. Stange EF, Travis SP, Vermeire S, Beglinger C, Kupcinkas L, Geboes K, Barakauskiene A, Villanacci V, Von Herbay A, Warren BF, Gasche C, Tilg H, Schreiber SW, Schölmerich J, Reinisch W, Organisation ECsaC (2006) European evidence based consensus on the diagnosis and management of Crohn's disease: 
definitions and diagnosis. Gut 55(Suppl 1):i1-i15. https://doi. org/10.1136/gut.2005.081950a

15. Sagar PM, Lewis W, Holdsworth PJ, Johnston D, Mitchell C, MacFie J (1993) Quality of life after restorative proctocolectomy with a pelvic ileal reservoir compares favorably with that of patients with medically treated colitis. Dis Colon Rectum 36(6):584-592. https://doi.org/10.1007/bf02049866

16. Vaizey CJ, Carapeti E, Cahill JA, Kamm MA (1999) Prospective comparison of faecal incontinence grading systems. Gut 44(1):77-80. https://doi.org/10.1136/gut.44.1.77

17. Magro F, Langner C, Driessen A, Ensari A, Geboes K, Mantzaris GJ, Villanacci V, Becheanu G, Borralho Nunes P, Cathomas G, Fries W, Jouret-Mourin A, Mescoli C, de Petris G, Rubio CA, Shepherd NA, Vieth M, Eliakim R, (ESP) ESoP, (ECCO) ECsaCO (2013) European consensus on the histopathology of inflammatory bowel disease. J Crohn's Colitis 7(10):827-851. https://doi.org/10.1016/j.crohns.2013.06.001

18. Santos MPC, Gomes C, Torres J (2018) Familial and ethnic risk in inflammatory bowel disease. Ann Gastroenterol 31(1):14-23. https://doi.org/10.20524/aog.2017.0208

19. Katsanos KH, Torres J, Roda G, Brygo A, Delaporte E, Colombel JF (2015) Review article: non-malignant oral manifestations in inflammatory bowel diseases. Aliment Pharmacol Ther 42(1):40-60. https://doi.org/10.1111/apt.13217

20. Lankarani KB, Sivandzadeh GR, Hassanpour S (2013) Oral manifestation in inflammatory bowel disease: a review. World J Gastroenterol WJG 19(46):8571-8579. https://doi.org/10.3748/wjg.v19.i46.8571

21. Haboubi N (2006) Small bowel inflammation in ulcerative colitis. Colorectal Dis 8(5):373-374. https://doi.org/10.111 1/j.1463-1318.2006.01043.x

22. Hamilton MJ, Makrauer FM, Golden K, Wang H, Friedman S, Burakoff RB, Levine JS, Joshi P, Banks PA, Odze RD (2016) Prospective evaluation of terminal ileitis in a surveillance population of patients with ulcerative colitis. Inflamm Bowel Dis 22(10):2448 2455. https://doi.org/10.1097/MIB.0000000000000911

23. Bell AJ, Price AB, Forbes A, Ciclitira PJ, Groves C, Nicholls RJ (2006) Pre-pouch ileitis: a disease of the ileum in ulcerative colitis after restorative proctocolectomy. Colorectal Dis 8(5):402-410. https://doi.org/10.1111/j.1463-1318.2006.00954.x

24. Zinicola R, Nicholls RJ (2004) Restorative proctocolectomy in patients with ulcerative colitis having a recto-vaginal fistula. Colorectal Dis 6(4):261-264. https://doi.org/10.111 1/j.1463-1318.2004.00606.x

25. Castiglione F, Mainenti PP, De Palma GD, Testa A, Bucci L, Pesce G, Camera L, Diaferia M, Rea M, Caporaso N, Salvatore M, Rispo A (2013) Noninvasive diagnosis of small bowel Crohn's disease: direct comparison of bowel sonography and magnetic resonance enterography. Inflamm Bowel Dis 19(5):991-998. https://doi.org/10.1097/MIB.0b013e3182802b87

26. Gauci J, Sammut L, Sciberras M, Piscopo N, Micallef K, Cortis K, Ellul P (2018) Small bowel imaging in Crohn's disease patients. Ann Gastroenterol 31(4):395-405. https://doi. org/10.20524/aog.2018.0268

27. Haas K, Rubesova E, Bass D (2016) Role of imaging in the evaluation of inflammatory bowel disease: how much is too much? World J Radiol 8(2):124-131. https://doi.org/10.4329/ wjr.v8.i2.124

28. Kopylov U, Yung DE, Engel T, Vijayan S, Har-Noy O, Katz L, Oliva S, Avni T, Battat R, Eliakim R, Ben-Horin S, Koulaouzidis A (2017) Diagnostic yield of capsule endoscopy versus magnetic resonance enterography and small bowel contrast ultrasound in the evaluation of small bowel Crohn's disease: systematic review and meta-analysis. Dig Liver Dis 49(8):854-863. https://doi. org/10.1016/j.dld.2017.04.013

29. Sciaudone G, Pellino G, Guadagni I, Pezzullo A, Selvaggi $F$ (2010) Wireless capsule endoscopy years after
Michelassi stricturoplasty for Crohn's disease. Acta Chir Belg 110(2):213-215

30. Lee SS, Kim AY, Yang SK, Chung JW, Kim SY, Park SH, Ha HK (2009) Crohn disease of the small bowel: comparison of CT enterography, MR enterography, and small-bowel follow-through as diagnostic techniques. Radiology 251(3):751-761. https://doi. org/10.1148/radiol.2513081184

31. Choi M, Lim S, Choi MG, Shim KN, Lee SH (2017) Effectiveness of capsule endoscopy compared with other diagnostic modalities in patients with small bowel Crohn's disease: a meta-analysis. Gut Liver 11(1):62-72. https://doi.org/10.5009/gnl16015

32. Catalano OA, Gee MS, Nicolai E, Selvaggi F, Pellino G, Cuocolo A, Luongo A, Catalano M, Rosen BR, Gervais D, Vangel MG, Soricelli A, Salvatore M (2015) Evaluation of quantitative PET/ MR enterography biomarkers for discrimination of inflammatory strictures from fibrotic strictures in Crohn disease. Radiology. https://doi.org/10.1148/radiol.2015150566

33. Pellino G, Nicolai E, Catalano OA, Campione S, D'Armiento FP, Salvatore M, Cuocolo A, Selvaggi F (2016) PET/MR versus PET/CT imaging: impact on the clinical management of smallbowel Crohn's disease. J Crohn's Colitis 10(3):277-285. https:// doi.org/10.1093/ecco-jcc/jjv207

34. Kim YS, Jung SA, Lee KM, Park SJ, Kim TO, Choi CH, Kim HG, Moon W, Moon CM, Song HK, Na SY, Yang SK, (KASID) KAftSoID (2017) Impact of inflammatory bowel disease on daily life: an online survey by the Korean Association for the Study of Intestinal Diseases. Intest Res 15(3):338-344. https://doi. org/10.5217/ir.2017.15.3.338

35. Byrne CM, Pager CK, Rex J, Roberts R, Solomon MJ (2002) Assessment of quality of life in the treatment of patients with neuropathic fecal incontinence. Dis Colon Rectum 45(11):14311436. https://doi.org/10.1007/s10350-004-6444-1

36. Siegel CA, Whitman CB, Spiegel BMR, Feagan B, Sands B, Loftus EV, Panaccione R, D'Haens G, Bernstein CN, Gearry R, Ng SC, Mantzaris GJ, Sartor B, Silverberg MS, Riddell R, Koutroubakis IE, O'Morain C, Lakatos PL, McGovern DPB, Halfvarson J, Reinisch W, Rogler G, Kruis W, Tysk C, Schreiber S, Danese S, Sandborn W, Griffiths A, Moum B, Gasche C, Pallone F, Travis S, Panes J, Colombel JF, Hanauer S, Peyrin-Biroulet L (2018) Development of an index to define overall disease severity in IBD. Gut 67(2):244-254. https://doi.org/10.1136/gutjnl-2016-312648

37. Guyatt G, Mitchell A, Irvine EJ, Singer J, Williams N, Goodacre R, Tompkins C (1989) A new measure of health status for clinical trials in inflammatory bowel disease. Gastroenterology 96(3):804-810

38. Satsangi J, Silverberg MS, Vermeire S, Colombel JF (2006) The Montreal classification of inflammatory bowel disease: controversies, consensus, and implications. Gut 55(6):749-753. https ://doi.org/10.1136/gut.2005.082909

39. Khanna R, Nelson SA, Feagan BG, D'Haens G, Sandborn WJ, Zou GY, MacDonald JK, Parker CE, Jairath V, Levesque BG (2016) Endoscopic scoring indices for evaluation of disease activity in Crohn's disease. Cochrane Database Syst Rev. https ://doi.org/10.1002/14651858.CD010642.pub2

40. Daperno M, D'Haens G, Van Assche G, Baert F, Bulois P, Maunoury V, Sostegni R, Rocca R, Pera A, Gevers A, Mary JY, Colombel JF, Rutgeerts P (2004) Development and validation of a new, simplified endoscopic activity score for Crohn's disease: the SES-CD. Gastrointest Endosc 60(4):505-512. https://doi. org/10.1016/s0016-5107(04)01878-4

41. Iacucci M, Daperno M, Lazarev M, Arsenascu R, Tontini GE, Akinola O, Gui XS, Villanacci V, Goetz M, Lowerison M, Lethebe BC, Vecchi M, Neumann H, Ghosh S, Bisschops R, Kiesslich R (2017) Development and reliability of the new endoscopic virtual chromoendoscopy score: the PICaSSO (Paddington International Virtual ChromoendoScopy ScOre) in ulcerative 
colitis. Gastrointest Endosc 86(6):1118-1127.e1115. https://doi. org/10.1016/j.gie.2017.03.012

42. Mohammed Vashist N, Samaan M, Mosli MH, Parker CE, MacDonald JK, Nelson SA, Zou GY, Feagan BG, Khanna R, Jairath V (2018) Endoscopic scoring indices for evaluation of disease activity in ulcerative colitis. Cochrane Database Syst Rev. https ://doi.org/10.1002/14651858.CD011450.pub2

43. Morar PS, Sevdalis N, Warusavitarne J, Hart A, Green J, Edwards C, Faiz O (2018) Establishing the aims, format and function for multidisciplinary team-driven care within an inflammatory bowel disease service: a multicentre qualitative specialist-based consensus study. Frontline Gastroenterol 9(1):29-36. https://doi. org/10.1136/flgastro-2017-100835

44. Molander P, Jussila A, Toivonen T, Mäkkeli P, Alho A, Kolho KL (2018) The impacts of an inflammatory bowel disease nurse specialist on the quality of care and costs in Finland. Scand J Gastroenterol 53(12):1463-1468. https://doi.org/10.1080/00365 521.2018 .1541477

45. Casellas F, Herrera-de Guise C, Robles V, Navarro E, Borruel N (2017) Patient preferences for inflammatory bowel disease treatment objectives. Dig Liver Dis 49(2):152-156. https://doi. org/10.1016/j.dld.2016.09.009

46. Morar P, Read J, Arora S, Hart A, Warusavitarne J, Green J, Sevdalis N, Edwards C, Faiz O (2015) Defining the optimal design of the inflammatory bowel disease multidisciplinary team: results from a multicentre qualitative expert-based study. Frontline Gastroenterol 6(4):290-297. https://doi.org/10.1136/flgastro-2014-100549

47. Ferrante M, D'Hoore A, Vermeire S, Declerck S, Noman M, Van Assche G, Hoffman I, Rutgeerts P, Penninckx F (2009) Corticosteroids but not infliximab increase short-term postoperative infectious complications in patients with ulcerative colitis. Inflamm Bowel Dis 15(7):1062-1070. https://doi.org/10.1002/ibd.20863

48. Aberra FN, Lewis JD, Hass D, Rombeau JL, Osborne B, Lichtenstein GR (2003) Corticosteroids and immunomodulators: postoperative infectious complication risk in inflammatory bowel disease patients. Gastroenterology 125(2):320-327. https://doi. org/10.1016/s0016-5085(03)00883-7

49. Mahadevan U, Loftus EV, Tremaine WJ, Pemberton JH, Harmsen WS, Schleck CD, Zinsmeister AR, Sandborn WJ (2002) Azathioprine or 6-mercaptopurine before colectomy for ulcerative colitis is not associated with increased postoperative complications. Inflamm Bowel Dis 8(5):311-316. https://doi.org/10.1097/00054 725-200209000-00001

50. El Hussuna A, Myrelid P, Holubar S, Kotze P, Mackenzie G, Pellino G, Winter D, Davies J, Negoi I, Grewal P, Gallo G, Sahnan K, Rubio-Perez I, Clerc D, Demartines N, Glasbey J, Regueiro M, Sherif A, Neary P, Pata F, Silverberg M, Clermont S, Chadi S, Emile S, Buchs N, Millan M, Minaya-Bravo A, Elfeki H, De Simone V, Shalaby M, Gutierrez C, Ozen C, Yalçınkaya A, Rivadeneira D, Sturiale A, Yassin N, Spinelli A, Warusavitarne J, Ioannidis A, Wexner S, Mayol J (2019) Biological treatment and the potential risk of adverse postoperative outcome in patients with inflammatory bowel disease: an open source expert panel review of the current literature and future perspectives. Crohn's Colitis. https://doi.org/10.1093/crocol/otz021

51. Yang Z, Wu Q, Wu K, Fan D (2010) Meta-analysis: pre-operative infliximab treatment and short-term post-operative complications in patients with ulcerative colitis. Aliment Pharmacol Ther 31(4):486-492. https://doi.org/10.1111/j.1365-2036.2009.04204.x

52. Rizzo G, Armuzzi A, Pugliese D, Verbo A, Papa A, Mattana C, Rapaccini GL, Guidi L, Coco C (2011) Anti-TNF-alpha therapies do not increase early postoperative complications in patients with inflammatory bowel disease: an Italian single-center experience. Int J Colorectal Dis 26(11):1435-1444. https://doi.org/10.1007/ s00384-011-1236-2
53. Nørgård BM, Nielsen J, Qvist N, Gradel KO, de Muckadell OB, Kjeldsen J (2013) Pre-operative use of anti-TNF- $\alpha$ agents and the risk of post-operative complications in patients with Crohn's disease - a nationwide cohort study. Aliment Pharmacol Ther 37(2):214-224. https://doi.org/10.1111/apt.12159

54. Zangenberg MS, Horesh N, Kopylov U, El-Hussuna A (2017) Preoperative optimization of patients with inflammatory bowel disease undergoing gastrointestinal surgery: a systematic review. Int J Colorectal Dis 32(12):1663-1676. https://doi.org/10.1007/ s00384-017-2915-4

55. Eshuis EJ, Al Saady RL, Stokkers PC, Ponsioen CY, Tanis PJ, Bemelman WA (2013) Previous infliximab therapy and postoperative complications after proctocolectomy with ileum pouch anal anastomosis. J Crohn's Colitis 7(2):142-149. https://doi. org/10.1016/j.crohns.2012.03.013

56. Selvaggi F, Pellino G, Canonico S, Sciaudone G (2015) Effect of preoperative biologic drugs on complications and function after restorative proctocolectomy with primary ileal pouch formation: systematic review and meta-analysis. Inflamm Bowel Dis 21(1):79-92. https://doi.org/10.1097/MIB.0000000000000232

57. Stoner PL, Kamel A, Ayoub F, Tan S, Iqbal A, Glover SC, Zimmermann EM (2018) Perioperative care of patients with inflammatory bowel disease: focus on nutritional support. Gastroenterol Res Pract 2018:7890161. https://doi.org/10.1155/2018/7890161

58. Li G, Ren J, Wang G, Hu D, Gu G, Liu S, Ren H, Wu X, Li J (2014) Preoperative exclusive enteral nutrition reduces the postoperative septic complications of fistulizing Crohn's disease. Eur J Clin Nutr 68(4):441-446. https://doi.org/10.1038/ejcn.2014.16

59. Forbes A, Escher J, Hébuterne X, Kłęk S, Krznaric Z, Schneider S, Shamir R, Stardelova K, Wierdsma N, Wiskin AE, Bischoff SC (2017) ESPEN guideline: clinical nutrition in inflammatory bowel disease. Clin Nutr 36(2):321-347. https://doi. org/10.1016/j.clnu.2016.12.027

60. Grass F, Pache B, Martin D, Hahnloser D, Demartines N, Hübner M (2017) Preoperative nutritional conditioning of Crohn's patients-systematic review of current evidence and practice. Nutrients. https://doi.org/10.3390/nu9060562

61. Kappelman MD, Horvath-Puho E, Sandler RS, Rubin DT, Ullman TA, Pedersen L, Baron JA, Sørensen HT (2011) Thromboembolic risk among Danish children and adults with inflammatory bowel diseases: a population-based nationwide study. Gut 60(7):937-943. https://doi.org/10.1136/gut.2010.228585

62. Novacek G, Weltermann A, Sobala A, Tilg H, Petritsch W, Reinisch W, Mayer A, Haas T, Kaser A, Feichtenschlager T, Fuchssteiner H, Knoflach P, Vogelsang H, Miehsler W, Platzer R, Tillinger W, Jaritz B, Schmid A, Blaha B, Dejaco C, Eichinger S (2010) Inflammatory bowel disease is a risk factor for recurrent venous thromboembolism. Gastroenterology 139(3):779-787. https://doi.org/10.1053/j.gastro.2010.05.026

63. Grainge MJ, West J, Card TR (2010) Venous thromboembolism during active disease and remission in inflammatory bowel disease: a cohort study. Lancet 375(9715):657-663. https://doi. org/10.1016/S0140-6736(09)61963-2

64. Merrill A, Millham F (2012) Increased risk of postoperative deep vein thrombosis and pulmonary embolism in patients with inflammatory bowel disease: a study of National Surgical Quality Improvement Program patients. Arch Surg 147(2):120-124. https ://doi.org/10.1001/archsurg.2011.297

65. Dignass A, Van Assche G, Lindsay JO, Lémann M, Söderholm J, Colombel JF, Danese S, D'Hoore A, Gassull M, Gomollón F, Hommes DW, Michetti P, O'Morain C, Oresland T, Windsor A, Stange EF, Travis SP, (ECCO) ECsaCO (2010) The second European evidence-based Consensus on the diagnosis and management of Crohn's disease: current management. J Crohn's Colitis 4(1):28-62. https://doi.org/10.1016/j.crohns.2009.12.002 
66. Brady MT, Patts GJ, Rosen A, Kasotakis G, Siracuse JJ, Sachs T, Kuhnen A, Kunitake H (2017) Postoperative venous thromboembolism in patients undergoing abdominal surgery for IBD: a common but rarely addressed problem. Dis Colon Rectum 60(1):61-67. https://doi.org/10.1097/DCR.0000000000000721

67. Gross ME, Vogler SA, Mone MC, Sheng X, Sklow B (2014) The importance of extended postoperative venous thromboembolism prophylaxis in IBD: a National Surgical Quality Improvement Program analysis. Dis Colon Rectum 57(4):482-489. https://doi. org/10.1097/DCR.0000000000000090

68. Research USDoHaHSFCfDEa, Research USDoHaHSFCfBEa, Health, USDoHaHSFCfDaR (2006) Guidance for industry: patient-reported outcome measures: use in medical product development to support labeling claims: draft guidance. Health Qual Life Outcomes 4:79. https://doi.org/10.1186/1477-7525-4-79

69. Bojic D, Bodger K, Travis S (2017) Patient reported outcome measures (PROMs) in inflammatory bowel disease: new data. $\mathbf{J}$ Crohn's Colitis 11:S576-S585. https://doi.org/10.1093/ecco-jcc/ jjw187

70. Harbord M, Eliakim R, Bettenworth D, Karmiris K, Katsanos K, Kopylov U, Kucharzik T, Molnár T, Raine T, Sebastian S, de Sousa HT, Dignass A, Carbonnel F, Organisation ECsaC, [ECCO] (2017) Third European evidence-based consensus on diagnosis and management of ulcerative colitis: part 2: current management. J Crohn's Colitis 11(7):769-784. https://doi. org/10.1093/ecco-jcc/jjx009

71. Burisch J, Jess T, Martinato M, Lakatos PL, EpiCom E (2013) The burden of inflammatory bowel disease in Europe. J Crohn's Colitis 7(4):322-337. https://doi.org/10.1016/j.crohn s.2013.01.010

72. Larsson S, Lawyer P, Garellick G, Lindahl B, Lundström M (2012) Use of 13 disease registries in 5 countries demonstrates the potential to use outcome data to improve health care's value. Health Aff (Millwood) 31(1):220-227. https://doi.org/10.1377/ hlthaff.2011.0762

73. Crandall WV, Margolis PA, Kappelman MD, King EC, Pratt JM, Boyle BM, Duffy LF, Grunow JE, Kim SC, Leibowitz I, Schoen BT, Colletti RB, Collaborative I (2012) Improved outcomes in a quality improvement collaborative for pediatric inflammatory bowel disease. Pediatrics 129(4):e1030-1041. https://doi. org/10.1542/peds.2011-1700

74. Peyrin-Biroulet L, Sandborn W, Sands BE, Reinisch W, Bemelman W, Bryant RV, D'Haens G, Dotan I, Dubinsky M, Feagan B, Fiorino G, Gearry R, Krishnareddy S, Lakatos PL, Loftus EV, Marteau P, Munkholm P, Murdoch TB, Ordás I, Panaccione R, Riddell RH, Ruel J, Rubin DT, Samaan M, Siegel CA, Silverberg MS, Stoker J, Schreiber S, Travis S, Van Assche G, Danese S, Panes J, Bouguen G, O'Donnell S, Pariente B, Winer S, Hanauer $S$, Colombel JF (2015) Selecting therapeutic targets in inflammatory bowel disease (STRIDE): determining therapeutic goals for treat-to-target. Am J Gastroenterol 110(9):1324-1338. https ://doi.org/10.1038/ajg.2015.233

75. Pouillon L, Peyrin-Biroulet L (2018) It is time to revise the STRIDE guidelines determining therapeutic goals for treatto-target in inflammatory bowel disease. J Crohn's Colitis 12(4):509. https://doi.org/10.1093/ecco-jcc/jjx174

76. Ma C, Hussein IM, Al-Abbar YJ, Panaccione R, Fedorak RN, Parker CE, Nguyen TM, Khanna R, Siegel CA, Peyrin-Biroulet L, Pai RK, Vande Casteele N, D'Haens GR, Sandborn WJ, Feagan BG, Jairath V (2018) Heterogeneity in definitions of efficacy and safety endpoints for clinical trials of crohn's disease: a systematic review. Clin Gastroenterol Hepatol 16(9):1407-1419. e1422. https://doi.org/10.1016/j.cgh.2018.02.051

77. Ma C, Panaccione R, Fedorak RN, Parker CE, Nguyen TM, Khanna R, Siegel CA, Peyrin-Biroulet L, D’Haens G, Sandborn WJ, Feagan BG, Jairath V (2018) Heterogeneity in definitions of endpoints for clinical trials of ulcerative colitis: a systematic review for development of a core outcome set. Clin Gastroenterol Hepatol 16(5):637-647.e613. https://doi.org/10.1016/j. cgh.2017.08.025

78. D'Haens G, Feagan B, Colombel JF, Sandborn WJ, Reinisch W, Rutgeerts P, Carbonnel F, Mary JY, Danese S, Fedorak RN, Hanauer S, Lémann M, (ECCO) IOfIBDIatCTCCotECsaCO (2012) Challenges to the design, execution, and analysis of randomized controlled trials for inflammatory bowel disease. Gastroenterology 143(6):1461-1469. https://doi.org/10.1053/j.gastr o.2012.09.031

79. Williamson PR, Altman DG, Blazeby JM, Clarke M, Devane D, Gargon E, Tugwell P (2012) Developing core outcome sets for clinical trials: issues to consider. Trials 13:132. https://doi. org/10.1186/1745-6215-13-132

80. Porter ME, Larsson S, Lee TH (2016) Standardizing patient outcomes measurement. N Engl J Med 374(6):504-506. https://doi. org/10.1056/NEJMp1511701

81. Kim AH, Roberts C, Feagan BG, Banerjee R, Bemelman W, Bodger K, Derieppe M, Dignass A, Driscoll R, Fitzpatrick R, Gaarentstroom-Lunt J, Higgins PD, Kotze PG, Meissner J, O'Connor M, Ran ZH, Siegel CA, Terry H, van Deen WK, van der Woude CJ, Weaver A, Yang SK, Sands BE, Vermeire S, Travis SP (2018) Developing a standard set of patient-centred outcomes for inflammatory bowel disease-an international, crossdisciplinary consensus. J Crohn's Colitis 12(4):408-418. https:// doi.org/10.1093/ecco-jcc/jjx161

82. Clara I, Lix LM, Walker JR, Graff LA, Miller N, Rogala L, Rawsthorne P, Bernstein CN (2009) The Manitoba IBD Index: evidence for a new and simple indicator of IBD activity. Am J Gastroenterol 104(7):1754-1763. https://doi.org/10.1038/ ajg.2009.197

83. Johnston WF, Stafford C, Francone TD, Read TE, Marcello PW, Roberts PL, Ricciardi R (2017) What is the risk of anastomotic leak after repeat intestinal resection in patients with Crohn's disease? Dis Colon Rectum 60(12):1299-1306. https://doi. org/10.1097/DCR.0000000000000946

84. Bouquot M, Maggiori L, Hain E, Prost A, la Denise J, Bouhnik Y, Panis Y (2019) What is the outcome for patients undergoing more than two ileocolonic resections for recurrent Crohn's disease? A comparative study of 569 consecutive procedures. Colorectal Dis 21(5):563-569. https://doi.org/10.1111/codi.14562

85. Egan L, D'Inca R, Jess T, Pellino G, Carbonnel F, Bokemeyer B, Harbord M, Nunes P, Van der Woude J, Selvaggi F, Triantafillidis J (2014) Non-colorectal intestinal tract carcinomas in inflammatory bowel disease: results of the 3rd ECCO Pathogenesis Scientific Workshop (II). J Crohn's Colitis 8(1):19-30. https:// doi.org/10.1016/j.crohns.2013.04.009

86. Laukoetter MG, Mennigen R, Hannig CM, Osada N, Rijcken E, Vowinkel T, Krieglstein CF, Senninger N, Anthoni C, Bruewer M (2011) Intestinal cancer risk in Crohn's disease: a meta-analysis. J Gastrointest Surg 15(4):576-583. https://doi.org/10.1007/ s11605-010-1402-9

87. Piton G, Cosnes J, Monnet E, Beaugerie L, Seksik P, Savoye G, Cadiot G, Flourie B, Capelle P, Marteau P, Lemann M, Colombel JF, Khouri E, Bonaz B, Carbonnel F (2008) Risk factors associated with small bowel adenocarcinoma in Crohn's disease: a case-control study. Am J Gastroenterol 103(7):1730-1736. https ://doi.org/10.1111/j.1572-0241.2008.01847.x

88. Vanoli A, Di Sabatino A, Martino M, Klersy C, Grillo F, Mescoli C, Nesi G, Volta U, Fornino D, Luinetti O, Fociani P, Villanacci V, D'Armiento FP, Cannizzaro R, Latella G, Ciacci C, Biancone L, Paulli M, Sessa F, Rugge M, Fiocca R, Corazza GR, Solcia E (2017) Small bowel carcinomas in celiac or Crohn's disease: distinctive histophenotypic, molecular and histogenetic patterns. 
Mod Pathol 30(10):1453-1466. https://doi.org/10.1038/modpa thol.2017.40

89. Scharl M, Frei P, Frei SM, Biedermann L, Weber A, Rogler G (2014) Epithelial-to-mesenchymal transition in a fistula-associated anal adenocarcinoma in a patient with long-standing Crohn's disease. Eur J Gastroenterol Hepatol 26(1):114-118. https://doi. org/10.1097/MEG.0b013e32836371a2

90. Baars JE, Kuipers EJ, Dijkstra G, Hommes DW, de Jong DJ, Stokkers PC, Oldenburg B, Pierik M, Wahab PJ, van Bodegraven AA, van der Woude CJ, IfCa C (2011) Malignant transformation of perianal and enterocutaneous fistulas is rare: results of 17 years of follow-up from The Netherlands. Scand J Gastroenterol 46(3):319-325. https://doi.org/10.3109/00365521.2010.536251

91. Lightdale CJ, Sternberg SS, Posner G, Sherlock P (1975) Carcinoma complicating Crohn's disease: report of seven cases and review of the literature. Am J Med 59(2):262-268. https://doi. org/10.1016/0002-9343(75)90361-7

92. Zefelippo A, Costa S, Caprioli F, Contessini-Avesani E (2015) Perianal Crohn's disease and fistula-associated carcinoma: challenges in diagnosis. Int J Colorectal Dis 30(11):1589-1591. https ://doi.org/10.1007/s00384-015-2140-y

93. Wisniewski A, Fléjou JF, Siproudhis L, Abramowitz L, Svrcek M, Beaugerie L (2017) Anal neoplasia in inflammatory bowel disease: classification proposal, epidemiology, carcinogenesis, and risk management perspectives. J Crohn's Colitis 11(8):10111018. https://doi.org/10.1093/ecco-jcc/jjx035

94. Traube J, Simpson S, Riddell RH, Levin B, Kirsner JB (1980) Crohn's disease and adenocarcinoma of the bowel. Dig Dis Sci 25(12):939-944. https://doi.org/10.1007/bf01308045

95. Slesser AA, Bhangu A, Bower M, Goldin R, Tekkis PP (2013) A systematic review of anal squamous cell carcinoma in inflammatory bowel disease. Surg Oncol 22(4):230-237. https://doi. org/10.1016/j.suronc.2013.08.002

96. Smith R, Hicks D, Tomljanovich PI, Lele SB, Rajput A, Dunn KB (2008) Adenocarcinoma arising from chronic perianal Crohn's disease: case report and review of the literature. Am Surg 74(1):59-61

97. Ball CS, Wujanto R, Haboubi NY, Schofield PF (1988) Carcinoma in anal Crohn's disease: discussion paper. J R Soc Med 81(4):217-219

98. Pellino G (2014) Immunosuppression may exert a hypoxia-mediated carcinogenetic effect in long-standing fistulizing Crohn's disease. Eur J Gastroenterol Hepatol 26:575-576. https://doi. org/10.1097/meg.0000000000000077

99. Freeman HJ, Perry T, Webber DL, Chang SD, Loh MY (2010) Mucinous carcinoma in Crohn's disease originating in a fistulous tract. World J Gastrointest Oncol 2(7):307-310. https://doi. org/10.4251/wjgo.v2.i7.307

100. Ky A, Sohn N, Weinstein MA, Korelitz BI (1998) Carcinoma arising in anorectal fistulas of Crohn's disease. Dis Colon Rectum 41(8):992-996. https://doi.org/10.1007/bf02237388

101. Devon KM, Brown CJ, Burnstein M, McLeod RS (2009) Cancer of the anus complicating perianal Crohn's disease. Dis Colon Rectum 52(2):211-216. https://doi.org/10.1007/DCR.0b013 e318197d0ad

102. Devroe H, Coene L, Mortelmans LJ, Jutten G (2005) Colloid carcinoma arising in an anorectal fistula in Crohn's disease: a case report. Acta Chir Belg 105(1):110-111

103. Iesalnieks I, Gaertner WB, Glass H, Strauch U, Hipp M, Agha A, Schlitt HJ (2010) Fistula-associated anal adenocarcinoma in Crohn's disease. Inflamm Bowel Dis 16(10):1643-1648. https ://doi.org/10.1002/ibd.21228

104. Benjelloun EB, Abkari M, Ousadden A, Ait-Taleb K (2013) Squamous cell carcinoma associated anal fistulas in Crohn's disease unique case report with literature review. J Crohn's
Colitis 7(6):e232-235. https://doi.org/10.1016/j.crohn s.2012.09.015

105. Gaertner WB, Hagerman GF, Finne CO, Alavi K, Jessurun J, Rothenberger DA, Madoff RD (2008) Fistula-associated anal adenocarcinoma: good results with aggressive therapy. Dis Colon Rectum 51(7):1061-1067. https://doi.org/10.1007/s1035 0-008-9294-4

106. Ogawa H, Haneda S, Shibata C, Miura K, Nagao M, Ohnuma S, Kohyama A, Unno M (2013) Adenocarcinoma associated with perianal fistulas in Crohn's disease. Anticancer Res 33(2):685-689

107. Stidham RW, Higgins PDR (2018) Colorectal cancer in inflammatory bowel disease. Clin Colon Rectal Surg 31(3):168-178. https://doi.org/10.1055/s-0037-1602237

108. Jess T, Gamborg M, Matzen P, Munkholm P, Sørensen TI (2005) Increased risk of intestinal cancer in Crohn's disease: a meta-analysis of population-based cohort studies. Am J Gastroenterol 100(12):2724-2729. https://doi.org/10.111 1/j.1572-0241.2005.00287.x

109. Jess T, Rungoe C, Peyrin-Biroulet L (2012) Risk of colorectal cancer in patients with ulcerative colitis: a meta-analysis of population-based cohort studies. Clin Gastroenterol Hepatol 10(6):639-645. https://doi.org/10.1016/j.cgh.2012.01.010

110. Collins PD, Mpofu C, Watson AJ, Rhodes JM (2006) Strategies for detecting colon cancer and/or dysplasia in patients with inflammatory bowel disease. Cochrane Database Syst Rev. https ://doi.org/10.1002/14651858.CD000279.pub3

111. Provenzale D, Wong JB, Onken JE, Lipscomb J (1998) Performing a cost-effectiveness analysis: surveillance of patients with ulcerative colitis. Am J Gastroenterol 93(6):872-880. https://doi. org/10.1111/j.1572-0241.1998.00314.x

112. Selvaggi F, Pellino G (2014) Cuff and pouch cancer in patients with inflammatory bowel disease: what surveillance strategy should be recommended? Reply. Inflamm Bowel Dis 20(8):E20E21. https://doi.org/10.1097/MIB.0000000000000097

113. Pellino G, Kontovounisios C, Tait D, Nicholls J, Tekkis PP (2017) Squamous cell carcinoma of the anal transitional zone after ileal pouch surgery for ulcerative colitis: systematic review and treatment perspectives. Case Rep Oncol 10(1):112-122. https://doi.org/10.1159/000455898

114. Pulusu SSR, Lawrance IC (2017) Dysplasia and colorectal cancer surveillance in inflammatory bowel disease. Expert Rev Gastroenterol Hepatol 11(8):711-722. https://doi.org/10.1080/17474 124.2017.1327347

115. Basseri RJ, Basseri B, Papadakis KA (2011) Dysplasia and cancer in inflammatory bowel disease. Expert Rev Gastroenterol Hepatol 5(1):59-66. https://doi.org/10.1586/egh.10.77

116. Beaugerie L, Svrcek M, Seksik P, Bouvier AM, Simon T, Allez M, Brixi H, Gornet JM, Altwegg R, Beau P, Duclos B, Bourreille A, Faivre J, Peyrin-Biroulet L, Fléjou JF, Carrat F, Group CS (2013) Risk of colorectal high-grade dysplasia and cancer in a prospective observational cohort of patients with inflammatory bowel disease. Gastroenterology 145(1):166-175. https://doi. org/10.1053/j.gastro.2013.03.044

117. Matkowskyj KA, Chen ZE, Rao MS, Yang GY (2013) Dysplastic lesions in inflammatory bowel disease: molecular pathogenesis to morphology. Arch Pathol Lab Med 137(3):338-350. https:// doi.org/10.5858/arpa.2012-0086-RA

118. Beaugerie L, Itzkowitz SH (2015) Cancers complicating inflammatory bowel disease. N Engl J Med 372(15):1441-1452. https ://doi.org/10.1056/NEJMra1403718

119. Keller DS, Windsor A, Cohen R, Chand M (2019) Colorectal cancer in inflammatory bowel disease: review of the evidence. Tech Coloproctol 23(1):3-13. https://doi.org/10.1007/s1015 1-019-1926-2 
120. Bettington M, Walker N, Clouston A, Brown I, Leggett B, Whitehall V (2013) The serrated pathway to colorectal carcinoma: current concepts and challenges. Histopathology 62(3):367-386. https://doi.org/10.1111/his.12055

121. Bossard C, Denis MG, Bézieau S, Bach-Ngohou K, Bourreille A, Laboisse CL, Mosnier JF (2007) Involvement of the serrated neoplasia pathway in inflammatory bowel disease-related colorectal oncogenesis. Oncol Rep 18(5):1093-1097

122. Kaltenbach T, Sandborn WJ (2017) Endoscopy in inflammatory bowel disease: advances in dysplasia detection and management. Gastrointest Endosc 86(6):962-971. https://doi.org/10.1016/j. gie.2017.09.030

123. Laine L, Kaltenbach T, Barkun A, McQuaid KR, Subramanian V, Soetikno R, Panel SGD (2015) SCENIC international consensus statement on surveillance and management of dysplasia in inflammatory bowel disease. Gastrointest Endosc 81(3):489-501. https://doi.org/10.1016/j.gie.2014.12.009

124. Schlemper RJ, Riddell RH, Kato Y, Borchard F, Cooper HS, Dawsey SM, Dixon MF, Fenoglio-Preiser CM, Fléjou JF, Geboes K, Hattori T, Hirota T, Itabashi M, Iwafuchi M, Iwashita A, Kim YI, Kirchner T, Klimpfinger M, Koike M, Lauwers GY, Lewin KJ, Oberhuber G, Offner F, Price AB, Rubio CA, Shimizu M, Shimoda T, Sipponen P, Solcia E, Stolte M, Watanabe H, Yamabe H (2000) The Vienna classification of gastrointestinal epithelial neoplasia. Gut 47(2):251-255. https://doi.org/10.1136/ gut.47.2.251

125. Odze RD (2006) Pathology of dysplasia and cancer in inflammatory bowel disease. Gastroenterol Clin North Am 35(3):533-552. https://doi.org/10.1016/j.gtc.2006.07.007

126. Svrcek M, Borralho Nunes $P$, Villanacci V, Beaugerie L, Rogler G, De Hertogh G, Tripathi M, Feakins R, Group H-E (2018) Clinicopathological and molecular specificities of inflammatory bowel disease-related colorectal neoplastic lesions: the role of inflammation. J Crohn's Colitis 12(12):1486-1498. https://doi. org/10.1093/ecco-jcc/jjy132

127. Pironi L, Arends J, Baxter J, Bozzetti F, Peláez RB, Cuerda C, Forbes A, Gabe S, Gillanders L, Holst M, Jeppesen PB, Joly F, Kelly D, Klek S, Irtun Ø, Olde Damink SW, Panisic M, Rasmussen HH, Staun M, Szczepanek K, Van Gossum A, Wanten G, Schneider SM, Shaffer J, Failure HANCI, ESPEN AIFSIGo (2015) ESPEN endorsed recommendations: definition and classification of intestinal failure in adults. Clin Nutr 34(2):171-180. https://doi.org/10.1016/j.clnu.2014.08.017

128. Pironi L, Corcos O, Forbes A, Holst M, Joly F, Jonkers C, Klek S, Lal S, Blaser AR, Rollins KE, Sasdelli AS, Shaffer J, Van Gossum A, Wanten G, Zanfi C, Lobo DN, Groups EAaCIFSI (2018) Intestinal failure in adults: recommendations from the ESPEN expert groups. Clin Nutr 37:1798-1809. https://doi. org/10.1016/j.clnu.2018.07.036

129. Uchino M, Ikeuchi H, Bando T, Matsuoka H, Takahashi Y, Takesue Y, Matsumoto T, Tomita N (2012) Risk factors for short bowel syndrome in patients with Crohn's disease. Surg Today 42(5):447-452. https://doi.org/10.1007/s00595-011-0098-0

130. Gearry RB, Kamm MA, Hart AL, Bassett P, Gabe SM, Nightingale JM (2013) Predictors for developing intestinal failure in patients with Crohn's disease. J Gastroenterol Hepatol 28(5):801-807. https://doi.org/10.1111/jgh.12115

131. Limketkai BN, Parian AM, Shah ND, Colombel JF (2016) Short bowel syndrome and intestinal failure in Crohn's disease. Inflamm Bowel Dis 22(5):1209-1218. https://doi.org/10.1097/ MIB.0000000000000698

132. Yamamoto T, Fazio VW, Tekkis PP (2007) Safety and efficacy of strictureplasty for Crohn's disease: a systematic review and meta-analysis. Dis Colon Rectum 50(11):1968-1986. https://doi. org/10.1007/s10350-007-0279-5
133. Morar PS, Hodgkinson JD, Thalayasingam S, Koysombat K, Purcell M, Hart AL, Warusavitarne J, Faiz O (2015) Determining predictors for intra-abdominal septic complications following ileocolonic resection for Crohn's disease-considerations in pre-operative and peri-operative optimisation techniques to improve outcome. J Crohn's Colitis 9(6):483-491. https://doi. org/10.1093/ecco-jcc/jjv051

134. Huang W, Tang Y, Nong L, Sun Y (2015) Risk factors for postoperative intra-abdominal septic complications after surgery in Crohn's disease: a meta-analysis of observational studies. $\mathbf{J}$ Crohn's Colitis 9(3):293-301. https://doi.org/10.1093/ecco-jcc/ jju028

135. Sigall-Boneh R, Levine A, Lomer M, Wierdsma N, Allan P, Fiorino G, Gatti S, Jonkers D, Kierkus J, Katsanos KH, Melgar S, Yuksel ES, Whelan K, Wine E, Gerasimidis K (2017) Research gaps in diet and nutrition in inflammatory bowel disease: a topical review by D-ECCO Working Group [Dietitians of ECCO]. J Crohn's Colitis 11(12):1407-1419. https://doi.org/10.1093/eccojcc/jjx 109

136. Sandhu A, Mosli M, Yan B, Wu T, Gregor J, Chande N, Ponich T, Beaton M, Rahman A (2016) Self-screening for malnutrition risk in outpatient inflammatory bowel disease patients using the malnutrition universal screening tool (MUST). JPEN J Parenter Enteral Nutr 40(4):507-510. https://doi.org/10.1177/0148607114 566656

137. Luo M, Fernández-Estívariz C, Manatunga AK, Bazargan N, Gu LH, Jones DP, Klapproth JM, Sitaraman SV, Leader LM, Galloway JR, Ziegler TR (2007) Are plasma citrulline and glutamine biomarkers of intestinal absorptive function in patients with short bowel syndrome? JPEN J Parenter Enteral Nutr 31(1):1-7. https ://doi.org/10.1177/014860710703100101

138. Stephens AN, Pereira-Fantini PM, Wilson G, Taylor RG, Rainczuk A, Meehan KL, Sourial M, Fuller PJ, Stanton PG, Robertson DM, Bines JE (2010) Proteomic analysis of the intestinal adaptation response reveals altered expression of fatty acid binding proteins following massive small bowel resection. J Proteome Res 9(3):1437-1449. https://doi.org/10.1021/pr900976f

139. Howard L, Ament M, Fleming CR, Shike M, Steiger E (1995) Current use and clinical outcome of home parenteral and enteral nutrition therapies in the United States. Gastroenterology 109(2):355-365. https://doi.org/10.1016/0016-5085(95)90321-6

140. Howard L, Heaphey L, Fleming CR, Lininger L, Steiger E (1991) Four years of North American registry home parenteral nutrition outcome data and their implications for patient management. JPEN J Parenter Enteral Nutr 15(4):384-393. https://doi. org/10.1177/0148607191015004384

141. Kalaiselvan R, Theis VS, Dibb M, Teubner A, Anderson ID, Shaffer JL, Carlson GL, Lal S (2014) Radiation enteritis leading to intestinal failure: 1994 patient-years of experience in a national referral centre. Eur J Clin Nutr 68(2):166-170. https:// doi.org/10.1038/ejen.2013.251

142. Gyorki DE, Brooks CE, Gett R, Woods RJ, Johnston M, Keck JO, Mackay JR, Heriot AG (2010) Enterocutaneous fistula: a singlecentre experience. ANZ J Surg 80(3):178-181. https://doi.org/1 0.1111/j.1445-2197.2009.05086.x

143. Staun M, Pironi L, Bozzetti F, Baxter J, Forbes A, Joly F, Jeppesen P, Moreno J, Hébuterne X, Pertkiewicz M, Mühlebach S, Shenkin A, Van Gossum A, ESPEN (2009) ESPEN guidelines on parenteral nutrition: home parenteral nutrition (HPN) in adult patients. Clin Nutr 28(4):467-479. https://doi.org/10.1016/j. clnu.2009.04.001

144. Vaizey CJ, Maeda Y, Barbosa E, Bozzetti F, Calvo J, Irtun Ø, Jeppesen PB, Klek S, Panisic-Sekeljic M, Papaconstantinou I, Pascher A, Panis Y, Wallace WD, Carlson G, Boermeester M, Group: EIF (2016) European Society of Coloproctology 
consensus on the surgical management of intestinal failure in adults. Colorectal Dis 18(6):535-548. https://doi.org/10.1111/ codi. 13321

145. Grainger JT, Maeda Y, Donnelly SC, Vaizey CJ (2018) Assessment and management of patients with intestinal failure: a multidisciplinary approach. Clin Exp Gastroenterol 11:233-241. https ://doi.org/10.2147/CEG.S122868

146. Ba'ath ME, Mahmalat MW, Kapur P, Smith NP, Dalzell AM, Casson DH, Lamont GL, Baillie CT (2007) Surgical management of inflammatory bowel disease. Arch Dis Child 92(4):312316. https://doi.org/10.1136/adc.2006.096875

147. Amil-Dias J, Kolacek S, Turner D, Pærregaard A, Rintala R, Afzal NA, Karolewska-Bochenek K, Bronsky J, Chong S, Fell J, Hojsak I, Hugot JP, Koletzko S, Kumar D, Lazowska-Przeorek I, Lillehei C, Lionetti P, Martin-de-Carpi J, Pakarinen M, Ruemmele FM, Shaoul R, Spray C, Staiano A, Sugarman I, Wilson DC, Winter H, Kolho KL, Group IWGoEIP (2017) Surgical management of crohn disease in children: guidelines from the paediatric IBD Porto Group of ESPGHAN. J Pediatr Gastroenterol Nutr 64(5):818-835. https://doi.org/10.1097/MPG.00000 00000001562

148. Di Abriola GF, De Angelis P, Dall'oglio L, Di Lorenzo M (2003) Strictureplasty: an alternative approach in long segment bowel stenosis Crohn's disease. J Pediatr Surg 38(5):814-818. https:// doi.org/10.1016/jpsu.2003.50173

149. Ruemmele FM, Veres G, Kolho KL, Griffiths A, Levine A, Escher JC, Amil Dias J, Barabino A, Braegger CP, Bronsky J, Buderus S, Martín-de-Carpi J, De Ridder L, Fagerberg UL, Hugot JP, Kierkus J, Kolacek S, Koletzko S, Lionetti P, Miele E, Navas López VM, Paerregaard A, Russell RK, Serban DE, Shaoul R, Van Rheenen P, Veereman G, Weiss B, Wilson D, Dignass A, Eliakim A, Winter H, Turner D, Organisation ECsaC, European Society of Pediatric Gastroenterology HpaN (2014) Consensus guidelines of ECCO/ESPGHAN on the medical management of pediatric Crohn's disease. J Crohn's Colitis 8(10):1179-1207. https://doi.org/10.1016/j.crohns.2014.04.005

150. de Zoeten EF, Pasternak BA, Mattei P, Kramer RE, Kader HA (2013) Diagnosis and treatment of perianal Crohn disease: NASPGHAN clinical report and consensus statement. J Pediatr Gastroenterol Nutr 57(3):401-412. https://doi.org/10.1097/ MPG.0b013e3182a025ee

151. Dharmaraj R, Nugent M, Simpson P, Arca M, Gurram B, Werlin $S$ (2018) Outcomes after fecal diversion for colonic and perianal Crohn disease in children. J Pediatr Surg 53(3):472-476. https ://doi.org/10.1016/j.jpedsurg.2017.08.011

152. Mattioli G, Pio L, Arrigo S, Pini Prato A, Montobbio G, Disma NM, Barabino A (2015) Cone-like resection, fistulectomy and mucosal rectal sleeve partial endorectal pull-through in paediatric Crohn's disease with perianal complex fistula. Dig Liver Dis 47(8):658-662. https://doi.org/10.1016/j.dld.2015.05.003

153. Simon T, Orangio G, Ambroze W, Schertzer M, Armstrong D (2003) Laparoscopic-assisted bowel resection in pediatric/adolescent inflammatory bowel disease: laparoscopic bowel resection in children. Dis Colon Rectum 46(10):1325-1331. https:// doi.org/10.1007/s10350-004-6742-7

154. von Allmen D, Markowitz JE, York A, Mamula P, Shepanski M, Baldassano R (2003) Laparoscopic-assisted bowel resection offers advantages over open surgery for treatment of segmental Crohn's disease in children. J Pediatr Surg 38(6):963-965. https ://doi.org/10.1016/s0022-3468(03)00134-9

155. Macaluso FS, Cavallaro F, Felice C, Mazza M, Armuzzi A, Gionchetti P, Vecchi M, Orlando A (2019) Risk factors and timing for colectomy in chronically active refractory ulcerative colitis: a systematic review. Dig Liver Dis 51(5):613-620. https://doi. org/10.1016/j.dld.2019.01.018
156. Tilney HS, Constantinides V, Ioannides AS, Tekkis PP, Darzi AW, Haddad MJ (2006) Pouch-anal anastomosis vs straight ileoanal anastomosis in pediatric patients: a meta-analysis. J Pediatr Surg 41(11):1799-1808. https://doi.org/10.1016/j.jpeds urg. 2006.06.005

157. Weston-Petrides GK, Lovegrove RE, Tilney HS, Heriot AG, Nicholls RJ, Mortensen NJ, Fazio VW, Tekkis PP (2008) Comparison of outcomes after restorative proctocolectomy with or without defunctioning ileostomy. Arch Surg 143(4):406-412. https://doi.org/10.1001/archsurg.143.4.406

158. Pellino G, Selvaggi F (2014) Restorative proctocolectomy in pediatric patients. J Am Coll Surg 219(5):1106. https://doi. org/10.1016/j.jamcollsurg.2014.07.938

159. Ross H, Steele SR, Varma M, Dykes S, Cima R, Buie WD, Rafferty J, Surgeons SPTFotASoCaR (2014) Practice parameters for the surgical treatment of ulcerative colitis. Dis Colon Rectum 57(1):5-22. https://doi.org/10.1097/DCR.0000000000000030

160. Mattioli G, Pini-Prato A, Barabino A, Gandullia P, Avanzini S, Guida E, Rossi V, Pio L, Disma N, Mameli L, Mirta DR, Montobbio G, Jasonni V (2011) Laparoscopic approach for children with inflammatory bowel diseases. Pediatr Surg Int 27(8):839-846. https://doi.org/10.1007/s00383-011-2885-5

161. Muntean A, Stoica I, McMahon SV, Mortell A, Gillick J, Sweeney BT (2019) Colectomies in children with inflammatory bowel disease: a national referral centre experience. Pediatr Surg Int 35(6):691-698. https://doi.org/10.1007/s00383-019-04467-4

162. Hait E, Arnold JH, Fishman LN (2006) Educate, communicate, anticipate-practical recommendations for transitioning adolescents with IBD to adult health care. Inflamm Bowel Dis 12(1):70 73. https://doi.org/10.1097/01.mib.0000194182.85047.6a

163. Goodhand J, Hedin CR, Croft NM, Lindsay JO (2011) Adolescents with IBD: the importance of structured transition care. J Crohn's Colitis 5(6):509-519. https://doi.org/10.1016/j.crohn s.2011.03.015

164. van Rheenen PF, Aloi M, Biron IA, Carlsen K, Cooney R, Cucchiara S, Cullen G, Escher JC, Kierkus J, Lindsay JO, Roma E, Russell RK, Sieczkowska-Golub J, Harbord M (2017) European Crohn's and colitis organisation topical review on transitional care in inflammatory bowel disease. J Crohn's Colitis 11(9):1032-1038. https://doi.org/10.1093/ecco-jcc/jjx010

165. Cole R, Ashok D, Razack A, Azaz A, Sebastian S (2015) Evaluation of outcomes in adolescent inflammatory bowel disease patients following transfer from pediatric to adult health care services: case for transition. J Adolesc Health 57(2):212-217. https://doi.org/10.1016/j.jadohealth.2015.04.012

166. Iannotti RJ, Schneider S, Nansel TR, Haynie DL, Plotnick LP, Clark LM, Sobel DO, Simons-Morton B (2006) Self-efficacy, outcome expectations, and diabetes self-management in adolescents with type 1 diabetes. J Dev Behav Pediatr 27(2):98-105

167. Izaguirre MR, Keefer L (2014) Development of a self-efficacy scale for adolescents and young adults with inflammatory bowel disease. J Pediatr Gastroenterol Nutr 59(1):29-32. https://doi. org/10.1097/MPG.0000000000000357

168. Izaguirre MR, Taft T, Keefer L (2017) Validation of a selfefficacy scale for adolescents and young adults with inflammatory bowel disease. J Pediatr Gastroenterol Nutr. https://doi. org/10.1097/mpg.0000000000001552

169. Higashiyama M, Sugita A, Koganei K, Wanatabe K, Yokoyama Y, Uchino M, Nagahori M, Naganuma M, Bamba S, Kato S, Takeuchi K, Omori T, Takagi T, Matsumoto S, Nagasaka M, Sagami S, Kitamura K, Katsurada T, Sugimoto K, Takatsu N, Saruta M, Sakurai T, Watanabe K, Nakamura S, Suzuki Y, Hokari R (2019) Correction to: Management of elderly ulcerative colitis in Japan. J Gastroenterol 54(10):936-937. https://doi.org/10.1007/ s00535-019-01606-5 
170. Colombo F, Pellino G, Sampietro G, Selvaggi F, Canonico S, Foschi D (2018) Surgical treatment of inflammatory bowel diseases in the elderly. Surgical management of elderly patients. Springer, Cham, pp 191-206

171. Arnott I, Rogler G, Halfvarson J (2018) The management of inflammatory bowel disease in elderly: current evidence and future perspectives. Inflamm Intest Dis 2(4):189-199. https:// doi.org/10.1159/000490053

172. Nguyen GC, Du L, Chong RY, Jackson TD (2019) Hypoalbuminaemia and postoperative outcomes in inflammatory bowel disease: the NSQIP surgical Cohort. J Crohn's Colitis. https:// doi.org/10.1093/ecco-jcc/jjz083

173. Kedia S, Limdi JK, Ahuja V (2018) Management of inflammatory bowel disease in older persons: evolving paradigms. Intest Res 16(2):194-208. https://doi.org/10.5217/ir.2018.16.2.194

174. Ananthakrishnan AN, Donaldson T, Lasch K, Yajnik V (2017) Management of inflammatory bowel disease in the elderly patient: challenges and opportunities. Inflamm Bowel Dis 23(6):882-893. https://doi.org/10.1097/MIB.0000000000001099

175. Hou JK, Feagins LA, Waljee AK (2016) Characteristics and behavior of elderly-onset inflammatory bowel disease: a multicenter US study. Inflamm Bowel Dis 22(9):2200-2205. https:// doi.org/10.1097/MIB.0000000000000849

176. Afzali A, Katz S (2018) Inflammatory bowel disease in the baby to baby boomer: pediatric and elderly onset of IBD. Curr Treat Options Gastroenterol 16(3):289-305. https://doi.org/10.1007/ s11938-018-0188-9

177. Sturm A, Maaser C, Mendall M, Karagiannis D, Karatzas P, Ipenburg N, Sebastian S, Rizzello F, Limdi J, Katsanos K, Schmidt C, Jeuring S, Colombo F, Gionchetti P (2017) European Crohn's and colitis organisation topical review on IBD in the elderly. J Crohn's Colitis 11(3):263-273. https://doi.org/10.1093/ecco-jcc/jjw188

178. Gisbert JP, Chaparro M (2014) Systematic review with meta-analysis: inflammatory bowel disease in the elderly. Aliment Pharmacol Ther 39(5):459-477. https://doi.org/10.1111/apt.12616

179. Pellino G, Sciaudone G, Candilio G, Camerlingo A, Marcellinaro R, Rocco F, De Fatico S, Canonico S, Selvaggi F (2013) Complications and functional outcomes of restorative proctocolectomy for ulcerative colitis in the elderly. BMC Surg 13:S9. https://doi. org/10.1186/1471-2482-13-S2-S9

180. Nguyen GC, Bernstein CN, Benchimol EI (2017) Risk of surgery and mortality in elderly-onset inflammatory bowel disease: a population-based cohort study. Inflamm Bowel Dis 23(2):218223. https://doi.org/10.1097/MIB.0000000000000993

181. Colombo PL, Tinozzi FP, Abelli M, Laera MR, Testone G, Moglia P, Albertario S, Morone G, Bianchi C, Tinozzi S (2002) Aspects of the complications after restorative proctocolectomy in the treatment of ulcerative colitis: review of the literature and personal experience. Ann Ital Chir 73(2):161-171 (discussion 171-162)

182. Williet N, Sarter H, Gower-Rousseau C, Adrianjafy C, Olympie A, Buisson A, Beaugerie L, Peyrin-Biroulet L (2017) Patientreported outcomes in a French nationwide survey of inflammatory bowel disease patients. J Crohn's Colitis 11(2):165-174. https://doi.org/10.1093/ecco-jcc/jjw145

183. Molodecky NA, Soon IS, Rabi DM, Ghali WA, Ferris M, Chernoff G, Benchimol EI, Panaccione R, Ghosh S, Barkema HW, Kaplan GG (2012) Increasing incidence and prevalence of the inflammatory bowel diseases with time, based on systematic review. Gastroenterology 142(1):46-54. https://doi. org/10.1053/j.gastro.2011.10.001(quiz e30)

184. Jackson BD, Gray K, Knowles SR, De Cruz P (2016) EHealth technologies in inflammatory bowel disease: a systematic review. J Crohn's Colitis 10(9):1103-1121. https://doi. org/10.1093/ecco-jcc/jjw059

185. Restellini S, Chao CY, Martel M, Barkun A, Kherad O, Seidman E, Wild G, Bitton A, Afif W, Bessissow T, Lakatos PL (2019) Clinical parameters correlate with endoscopic activity of ulcerative colitis: a systematic review. Clin Gastroenterol Hepatol 17(7):1265-1275. e1268. https://doi.org/10.1016/j.cgh.2018.12.021

186. Khanna R, Zou G, D'Haens G, Feagan BG, Sandborn WJ, Vandervoort MK, Rolleri RL, Bortey E, Paterson C, Forbes WP, Levesque BG (2015) A retrospective analysis: the development of patient reported outcome measures for the assessment of Crohn's disease activity. Aliment Pharmacol Ther 41(1):77-86. https://doi.org/10.1111/apt.13001

187. Chung AE, Sandler RS, Long MD, Ahrens S, Burris JL, Martin CF, Anton K, Robb A, Caruso TP, Jaeger EL, Chen W, Clark M, Myers K, Dobes A, Kappelman MD (2016) Harnessing person-generated health data to accelerate patient-centered outcomes research: the Crohn's and Colitis Foundation of America PCORnet Patient Powered Research Network (CCFA Partners). J Am Med Inform Assoc 23(3):485-490. https://doi.org/10.1093/jamia/ocv191

188. Armstrong MJ, Bloom JA (2017) Patient involvement in guidelines is poor five years after institute of medicine standards: review of guideline methodologies. Res Involv Engagem 3:19. https://doi.org/10.1186/s40900-017-0070-2

189. Kirwan JR, de Wit M, Frank L, Haywood KL, Salek S, BraceMcDonnell S, Lyddiatt A, Barbic SP, Alonso J, Guillemin F, Bartlett SJ (2017) Emerging guidelines for patient engagement in research. Value Health 20(3):481-486. https://doi. org/10.1016/j.jval.2016.10.003

190. van de Bovenkamp HM, Zuiderent-Jerak T (2015) An empirical study of patient participation in guideline development: exploring the potential for articulating patient knowledge in evidence-based epistemic settings. Health Expect 18(5):942955. https://doi.org/10.1111/hex.12067

191. Morar PS, Hollingshead J, Bemelman W, Sevdalis N, Pinkney T, Wilson G, Dunlop M, Davies RJ, Guy R, Fearnhead N, Brown S, Warusavitarne J, Edwards C, Faiz O (2017) Establishing key performance indicators [kpis] and their importance for the surgical management of inflammatory bowel disease-results from a Pan-European, Delphi Consensus Study. J Crohn's Colitis 11(11):1362-1368. https://doi.org/10.1093/ecco-jcc/jjx099

192. Egberg MD, Galanko JA, Kappelman MD (2019) Patients who undergo colectomy for pediatric ulcerative colitis at low-volume hospitals have more complications. Clin Gastroenterol Hepatol. https://doi.org/10.1016/j.cgh.2019.03.003

193. Raval MJ, Schnitzler M, O'Connor BI, Cohen Z, McLeod RS (2007) Improved outcome due to increased experience and individualized management of leaks after ileal pouch-anal anastomosis. Ann Surg 246(5):763-770. https://doi.org/10.1097/ SLA.0b013e31814539b1

194. Bemelman WA, Collaborators S-E (2018) Evolving role of IBD surgery. J Crohn's Colitis 12(8):1005-1007. https://doi. org/10.1093/ecco-jcc/jjy056

195. Bemelman WA, Warusavitarne J, Sampietro GM, Serclova Z, Zmora O, Luglio G, de Buck-van-Overstraeten A, Burke JP, Buskens CJ, Colombo F, Dias JA, Eliakim R, Elosua T, Gecim IE, Kolacek S, Kierkus J, Kolho KL, Lefevre JH, Millan M, Panis Y, Pinkney T, Russell RK, Shwaartz C, Vaizey C, Yassin N, D'Hoore A (2018) ECCO-ESCP consensus on surgery for Crohn's disease. J Crohn's Colitis 12(1):1-16. https://doi.org/10.1093/ecco-jcc/jjx061

196. Law CC, Sasidharan S, Rodrigues R, Nguyen DD, Sauk J, Garber J, Giallourakis C, Xavier R, Khalili H, Yajnik V, Ananthakrishnan AN (2016) Impact of specialized inpatient IBD care on outcomes of IBD hospitalizations: a cohort study. Inflamm Bowel Dis 22(9):2149-2157. https://doi.org/10.1097/MIB.00000 00000000870

197. Bitton A, Dobkin PL, Edwardes MD, Sewitch MJ, Meddings JB, Rawal S, Cohen A, Vermeire S, Dufresne L, Franchimont D, Wild GE (2008) Predicting relapse in Crohn's disease: a 
biopsychosocial model. Gut 57(10):1386-1392. https://doi. org/10.1136/gut.2007.134817

198. Bitton A, Vutcovici M, Lytvyak E, Kachan N, Bressler B, Jones J, Lakatos PL, Sewitch M, El-Matary W, Melmed G, Nguyen G, Group Qc, program, PAaCtCoE-P (2019) Selection of Quality Indicators in IBD: integrating physician and patient perspectives. Inflamm Bowel Dis 25(2):403-409. https://doi.org/10.1093/ibd/ izy 259

199. Holder-Murray J, Marsicovetere P, Holubar SD (2015) Minimally invasive surgery for inflammatory bowel disease. Inflamm Bowel Dis 21(6):1443-1458. https://doi.org/10.1097/MIB.0000000000 000316

200. Maggiori L, Khayat A, Treton X, Bouhnik Y, Vicaut E, Panis Y (2014) Laparoscopic approach for inflammatory bowel disease is a real alternative to open surgery: an experience with 574 consecutive patients. Ann Surg 260(2):305-310. https://doi. org/10.1097/SLA.0000000000000534

201. Mackenzie H, Miskovic D, Ni M, Parvaiz A, Acheson AG, Jenkins JT, Griffith J, Coleman MG, Hanna GB (2013) Clinical and educational proficiency gain of supervised laparoscopic colorectal surgical trainees. Surg Endosc 27(8):2704-2711. https://doi. org/10.1007/s00464-013-2806-X

202. Celentano V, Finch D, Forster L, Robinson JM, Griffith JP (2015) Safety of supervised trainee-performed laparoscopic surgery for inflammatory bowel disease. Int J Colorectal Dis 30(5):639-644. https://doi.org/10.1007/s00384-015-2147-4
203. Celentano V, Flashman KG (2019) Stepwise training in laparoscopic surgery for complex ileocolonic Crohn's disease: analysis of 127 training episodes. J Surg Educ 76(5):1364-1369. https:// doi.org/10.1016/j.jsurg.2019.03.009

204. Pellino G, Selvaggi F, Ghezzi G, Corona D, Riegler G, Delaini GG (2015) A think tank of the Italian Society of Colorectal Surgery (SICCR) on the surgical treatment of inflammatory bowel disease using the Delphi method: Crohn's disease. Tech Coloproctol 19(10):639-651. https://doi.org/10.1007/s10151-015-1368-4

205. Selvaggi F, Pellino G, Ghezzi G, Corona D, Riegler G, Delaini GG (2015) A think tank of the Italian Society of Colorectal Surgery (SICCR) on the surgical treatment of inflammatory bowel disease using the Delphi method: ulcerative colitis. Tech Coloproctol 19(10):627-638. https://doi.org/10.1007/s10151-015-1367-5

206. Gajendran M, Loganathan P, Catinella AP, Hashash JG (2018) A comprehensive review and update on Crohn's disease. Dis Mon 64(2):20-57. https://doi.org/10.1016/j.disamonth.2017.07.001

207. Romeo E, Jasonni V, Caldaro T, Barabino A, Mattioli G, Vignola S, di Abriola GF, De Angelis P, Pane A, Torroni F, Rea F, Dall'Oglio L (2012) Strictureplasty and intestinal resection: different options in complicated pediatric-onset Crohn disease. J Pediatr Surg 47(5):944-948. https://doi.org/10.1016/j.jpeds urg.2012.01.054

Publisher's Note Springer Nature remains neutral with regard to jurisdictional claims in published maps and institutional affiliations.

\section{Affiliations}

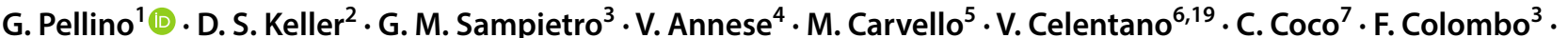

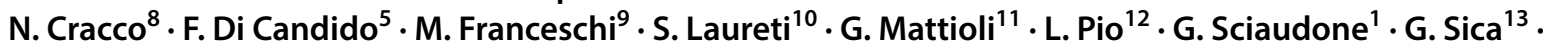 V. Villanacci ${ }^{14} \cdot$ R. Zinicola ${ }^{15} \cdot$ S. Leone ${ }^{16} \cdot$ S. Danese ${ }^{17} \cdot$ A. Spinelli ${ }^{5} \cdot$ G. Delaini ${ }^{18} \cdot$ F. Selvaggi $^{1}$ on behalf of the Italian Society of Colorectal Surgery (SICCR)}

1 Colorectal Surgery, Department of Advanced Medical and Surgical Sciences, Università Degli Studi Della Campania "Luigi Vanvitelli", Policlinico CS, Piazza Miraglia 2, 80138 Naples, Italy

2 Division of Colon and Rectal Surgery, Department of Surgery, NewYork-Presbyterian, Columbia University Medical Center, New York, USA

3 L. Sacco University Hospital Milano, Milan, Italy

4 Gastroenterology Unit, DEA-Medicina E Chirurgia Generale E D’Urgenza, University Hospital Careggi, Firenze, Italy

5 Colon and Rectal Surgery Division, Humanitas Clinical and Research Center, Rozzano, Milan, Italy

6 Portsmouth Hospitals NHS Trust, Portsmouth, UK

7 UOC Chirurgia Generale 2, Università Cattolica del Sacro Cuore, Fondazione Policlinico Universitario A. Gemelli-IRCCS, Rome, Italy

8 Department of General Surgery, IRCCS Sacro Cuore Don Calabria Hospital, Negrar, Verona, Italy

9 IBD Surgery, Azienda Ospedaliero Universitaria Pisana, Pisa, Italy

10 Surgery of the Alimentary Tract, Sant'Orsola Hospital, Department of Medical and Surgical Sciences, Alma Mater Studiorum University of Bologna, Bologna, Italy
11 Pediatric Surgery Unit, Istituto Giannina Gaslini, and Department of Neuroscience, Rehabilitation, Ophthalmology, Genetics, Maternal and Child Health (DINOGMI), University of Genoa, Genoa, Italy

12 Pediatric Surgery Department, Hôpital Robert-Debré and Université de Paris, Paris, France

13 Minimally Invasive and Gastro-Intestinal Unit, Department of Surgery, Policlinico Tor Vergata, Rome, Italy

14 Institute of Pathology, Spedali Civili Brescia, Brescia, Italy

15 Department of Emergency Surgery, University Hospital Parma, Parma, Italy

16 CEO, Associazione Nazionale Per Le Malattie Infiammatorie Croniche Dell'Intestino “A.M.I.C.I. Onlus”, Milan, Italy

17 Division of Gastroenterology, IBD Center, Humanitas University, Rozzano, Milan, Italy

18 Department of Surgery, "Pederzoli" Hospital, Peschiera del Garda, Verona, Italy

19 University of Portsmouth, Portsmouth, UK 